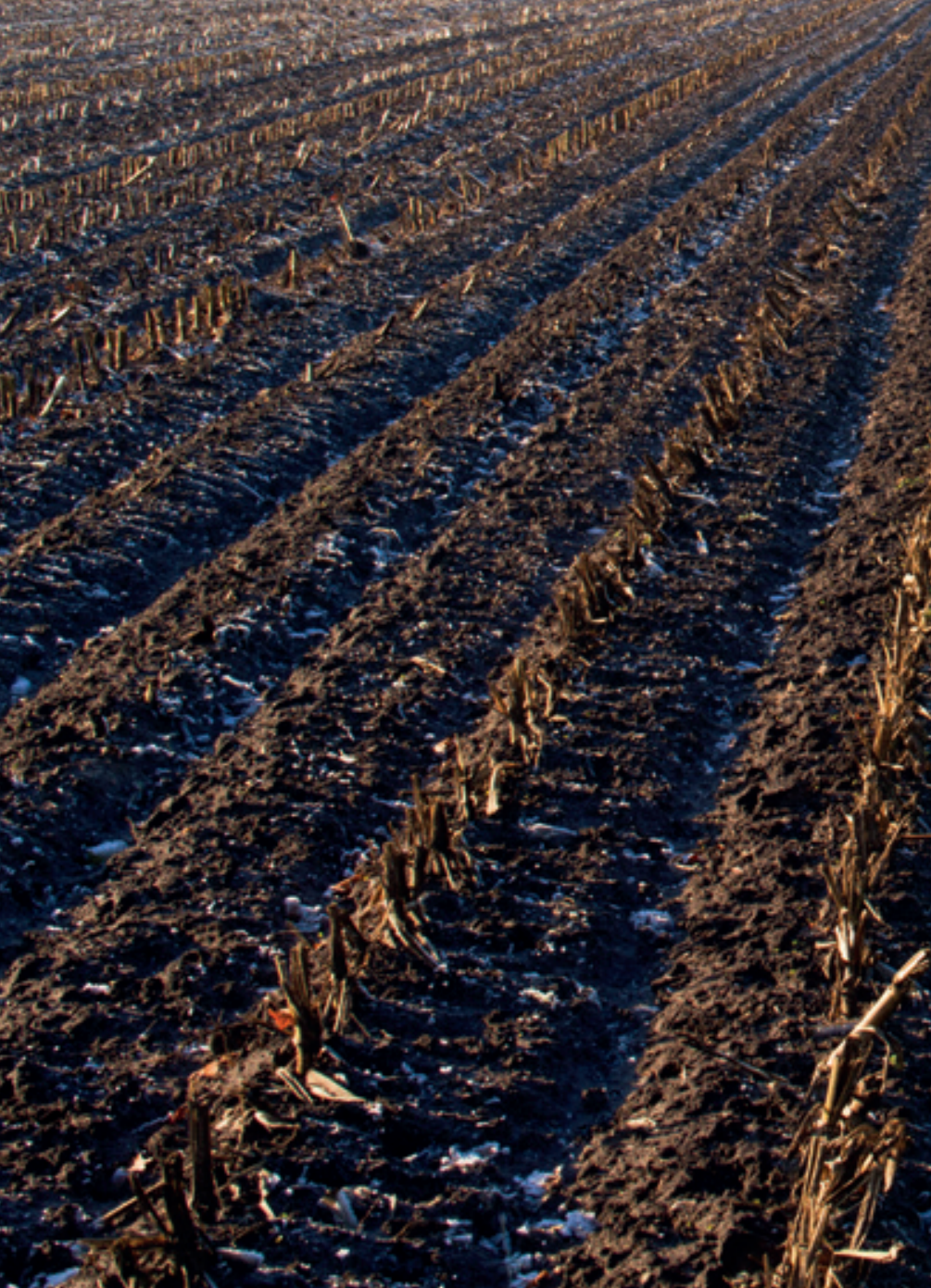

\title{
notit
}

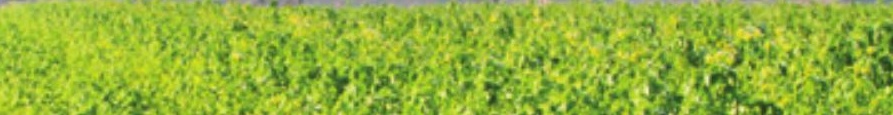

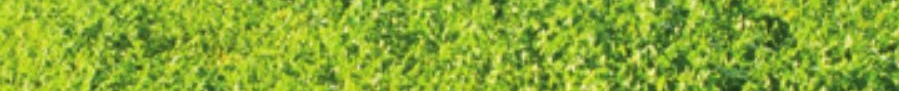

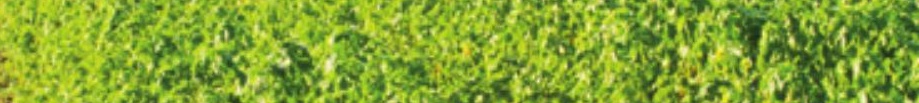

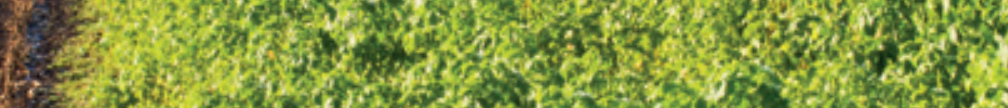

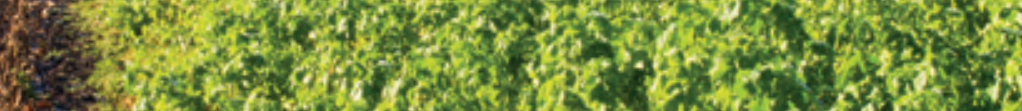

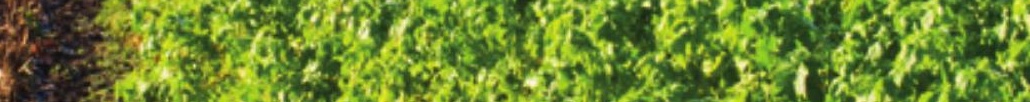

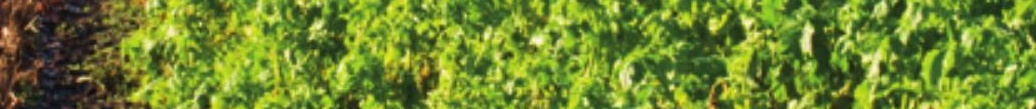

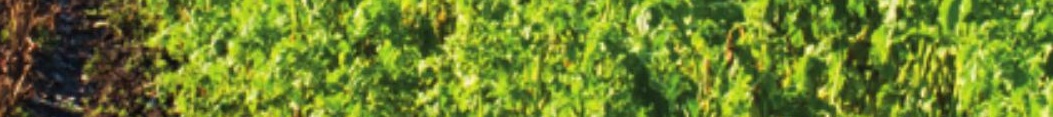

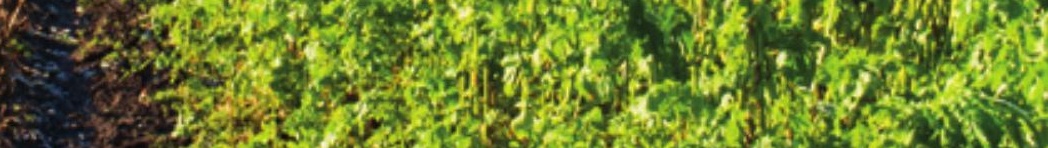
4.5.

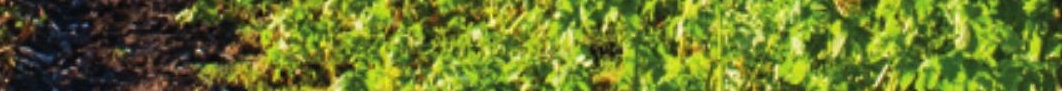

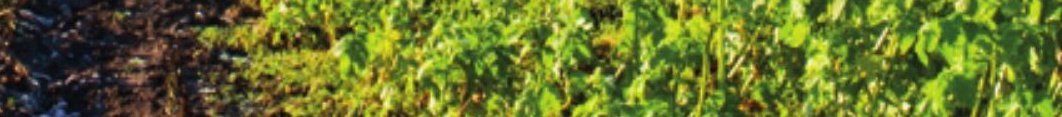
S.

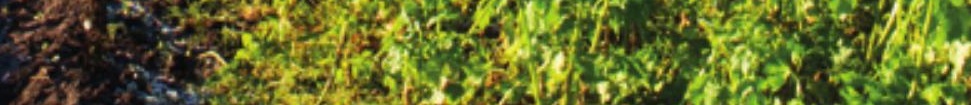
2. 20.

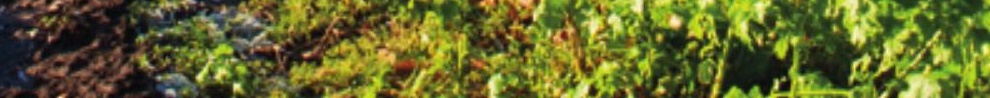

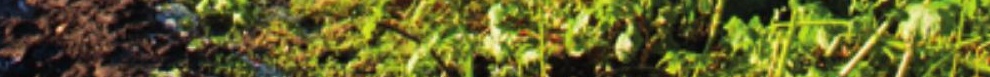

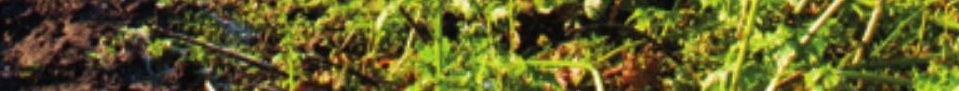

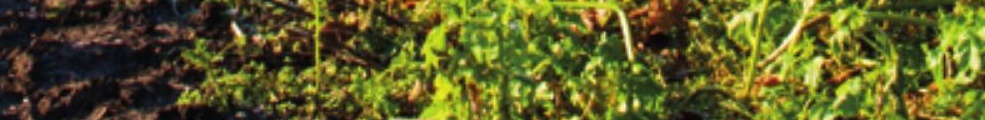
4⿻一𠃋

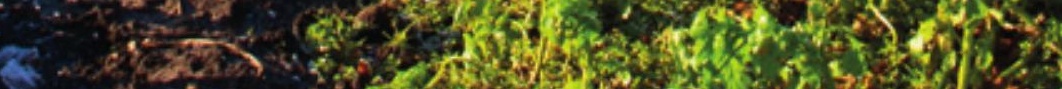
\& -6 -

\section{Ontwikkeling praktijktool voor bodem C}

Jan Peter Lesschen, Chantal Hendriks, Annelotte van der Linden, Bart Timmermans, Joost Keuskamp,

Dirk Keuper, Marjoleine Hanegraaf, Sjaak Conijn, Thalisa Slier 



\section{Ontwikkeling praktijktool voor bodem C}

Jan Peter Lesschen ${ }^{1}$, Chantal Hendriks ${ }^{1}$, Annelotte van der Linden ${ }^{1}$, Bart Timmermans ${ }^{2}$, Joost Keuskamp ${ }^{3 / 4}$, Dirk Keuper ${ }^{3}$, Marjoleine Hanegraaf ${ }^{5}$, Sjaak Conijn ${ }^{5}$, Thalisa Slier ${ }^{1}$

1 Wageningen Environmental Research

2 Louis Bolk Instituut

3 CLM Onderzoek en Advies BV

4 Biont Research

5 Wageningen Plant Research

Dit onderzoek is uitgevoerd door Wageningen Environmental Research, Louis Bolk Instituut, CLM Onderzoek en Advies BV en Wageningen Plant Research in opdracht van en gefinancierd door het ministerie van Landbouw, Natuur en Voedselkwaliteit, in het kader van het Beleidsondersteunend onderzoek binnen het klimaatenvelop programma Slim landgebruik (projectnummer BO-53-002-009). Wageningen Environmental Research

Wageningen, maart 2020

Gereviewd door:

Gert Jan Reinds, teamleider van Duurzaam Bodemgebruik

Akkoord voor publicatie:

Gert Jan Reinds, teamleider van Duurzaam Bodemgebruik 
Lesschen, J.P., Hendriks, C.M.J., van der Linden, A., Keuskamp, J., Keuper, D., Timmermans, B., Hanegraaf, M., Conijn, S., Slier, T., 2020. Ontwikkeling praktijktool voor bodem C. Wageningen, Wageningen Environmental Research, Rapport 2990. 50 blz.; 6 fig.; 6 tab.; 24 ref.

In het Klimaatakkoord is voor landbouwbodems een doelstelling van 0,5 Mton $\mathrm{CO}_{2}$-vastlegging per jaar in 2030 voorgesteld. Om dit te realiseren, is er behoefte aan een praktijktool die op perceel- en bedrijfsniveau veranderingen in bodem C-voorraad kan berekenen en het effect van bodem $\mathrm{C}$-maatregelen kan kwantificeren. Uit een inventarisatie van mogelijke bodem C-modellen zijn er drie geselecteerd: CCB, NDICEA en RothC. De databehoefte van de modellen is in kaart gebracht en de modellen zijn getest aan de hand van twee langetermijndatasets, de 'Mest als Kans'-proef en een langetermijnexperiment van proefboerderij Vredepeel. De keuze voor welk model te gebruiken als praktijktool hangt af van de beoogde toepassing. Wanneer de tool alleen voor monitoring van bodem C geschikt moet zijn, zou RothC een logische keuze zijn vanwege de minimale data-invoer en de mogelijkheid om makkelijk grote datasets (veel percelen) door te rekenen. Als het doel gericht is op advisering van boeren zou NDICEA geschikter zijn, omdat het meer indicatoren berekent en interacties met stikstof- (en fosfaat)bemesting meeneemt. CCB zit hier qua gebruikersgemak en databehoefte tussenin.

Trefwoorden: systeemmodellen, koolstofkringloop, koolstofvastlegging, bodem

Dit rapport is gratis te downloaden van https://doi.org/10.18174/517746 of op www.wur.nl/environmental-research (ga naar 'Wageningen Environmental Research' in de grijze balk onderaan). Wageningen Environmental Research verstrekt geen gedrukte exemplaren van rapporten.

\section{CC license CC-BY-NC 4.0}

(2) 2020 Wageningen Environmental Research (instituut binnen de rechtspersoon Stichting Wageningen Research), Postbus 47, 6700 AA Wageningen, T 0317480700 ,

www.wur.nl/environmental-research. Wageningen Environmental Research is onderdeel van Wageningen University \& Research.

- Overname, verveelvoudiging of openbaarmaking van deze uitgave is toegestaan mits met duidelijke bronvermelding.

- Overname, verveelvoudiging of openbaarmaking is niet toegestaan voor commerciële doeleinden en/of geldelijk gewin.

- Overname, verveelvoudiging of openbaarmaking is niet toegestaan voor die gedeelten van deze uitgave waarvan duidelijk is dat de auteursrechten liggen bij derden en/of zijn voorbehouden.

Wageningen Environmental Research aanvaardt geen aansprakelijkheid voor eventuele schade voortvloeiend uit het gebruik van de resultaten van dit onderzoek of de toepassing van de adviezen.

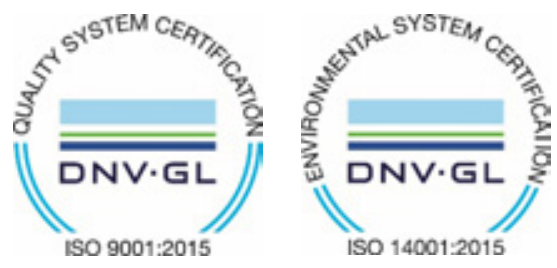

Wageningen Environmental Research werkt sinds 2003 met een ISO 9001 gecertificeerd kwaliteitsmanagementsysteem. In 2006 heeft Wageningen Environmental Research een milieuzorgsysteem geïmplementeerd, gecertificeerd volgens de norm ISO 14001.

Wageningen Environmental Research geeft via ISO 26000 invulling aan haar maatschappelijke verantwoordelijkheid.

Wageningen Environmental Research Rapport 2990 | ISSN 1566-7197

Foto omslag: Shutterstock 


\section{Inhoud}

Verantwoording $\quad 5$

$\begin{array}{ll}\text { Samenvatting } & 7\end{array}$

1

$\begin{array}{ll}\text { Introductie } & 9\end{array}$

1.1 Achtergrond $\quad 9$

$\begin{array}{lll}1.2 & \text { Doelstelling } & 9\end{array}$

$\begin{array}{lll}1.3 & \text { Aanpak } & 10\end{array}$

2

$\begin{array}{ll}\text { Programma van eisen } & 11\end{array}$

3

$\begin{array}{ll}\text { Analyse bestaande koolstofmodellen } & 12\end{array}$

3.1 Keuze modellen $\quad 12$

3.1.1 CANDY 12

3.1.2 CANDY Carbon Balance (CCB) 12

$\begin{array}{ll}3.1 .3 \text { Century } & 12\end{array}$

3.1.4 Cool Farm Tool 12

$\begin{array}{lll}3.1 .5 & \text { DayCent } & 13\end{array}$

3.1.6 DeNitrification-DeComposition (DNDC) 13

$\begin{array}{lll}3.1 .7 & E P I C & 13\end{array}$

$\begin{array}{lll}3.1 .8 & \text { NDICEA } & 13\end{array}$

$\begin{array}{lll}3.1 .9 & \text { ORCHIDEE } & 13\end{array}$

3.1.10 OS balans NMI 13

3.1.11 OS-balans Productschap Akkerbouw 14

3.1 .12 RothC 14

3.2 Criteria voor beoordeling $\quad 14$

$\begin{array}{lll}3.3 & \text { Resultaat analyse } & 17\end{array}$

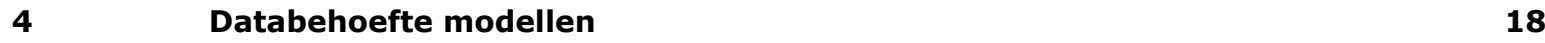

$5 \quad$ Kwantitatieve vergelijking modellen $\quad 20$

$5.1 \quad$ Beschrijving testdataset $\quad 20$

5.1.1 Proeflocatie Mest Als Kans in Lelystad 20

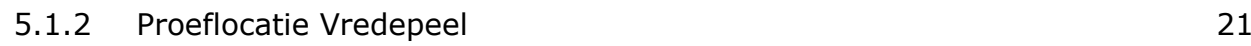

$\begin{array}{lll}5.2 & \text { Beschrijving aanpak } & 21\end{array}$

5.3 Resultaten 23

5.3.1 Koolstofaanvoer 23

$\begin{array}{ll}5.3 .2 \text { Koolstofvoorraad } & 24\end{array}$

$\begin{array}{lll}5.4 & \text { Discussie } & 25\end{array}$

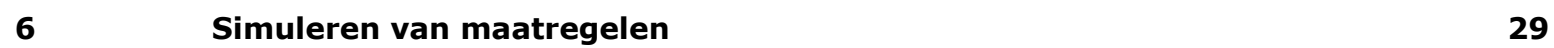

$\begin{array}{lll}6.1 & \text { Grondbewerking } & 29\end{array}$

$\begin{array}{lll}6.1 .1 & \text { NDICEA } & 29\end{array}$

$\begin{array}{lll}6.1 .2 \mathrm{CCB} & 30\end{array}$

6.1.3 RothC 31

6.2 Externe aanvoer organische stof 31

6.2.1 NDICEA 31

6.2.2 CCB 31

6.2.3 RothC 31 
6.3 Interne input organische stof $\quad 32$

6.3.1 NDICEA

6.3.2 CCB

6.3.3 RothC 32

7

Conclusies en aanbevelingen

34

Literatuur

35

Bijlage 1 Gedetailleerde beschrijving bodem C-modellen 


\section{Verantwoording}

Rapport: 2990

Projectnummer: 5200044766

Wageningen Environmental Research (WENR) hecht grote waarde aan de kwaliteit van zijn eindproducten. Een review van de rapporten op wetenschappelijke kwaliteit door een referent maakt standaard onderdeel uit van ons kwaliteitsbeleid.

Akkoord Referent die het rapport heeft beoordeeld,

functie: teamleider van Duurzaam Bodemgebruik

naam: Gert Jan Reinds

datum: $\quad 02-03-2020$

Akkoord teamleider voor de inhoud,

naam: Gert Jan Reinds

datum: $\quad 02-03-2020$ 


\section{Samenvatting}

De landbouwsector kan op verschillende manieren bijdragen aan de klimaatdoelstellingen. Zo kunnen boeren aanpassingen doen in hun bodembeheer die ervoor zorgen dat er meer $\mathrm{CO}_{2}$ opgeslagen of vastgehouden wordt in de bodem (bodem C-maatregelen). In het Klimaatakkoord is voor landbouwbodems een doelstelling van 0,5 Mton $\mathrm{CO}_{2}$-vastlegging per jaar opgenomen in 2030. Om dit te realiseren, is er behoefte aan een praktijkmodel dat op perceel- en bedrijfsniveau veranderingen in bodem C-voorraad kan berekenen en het effect van bodem C-maatregelen kan kwantificeren. Het doel van deze studie is om vanuit bestaande bodem C-modellen één of meerdere praktijkmodellen te identificeren. Het praktijkmodel moet toepasbaar zijn in Nederlandse condities, zich lenen voor opschaling en bodem C-maatregelen door kunnen rekenen om de netto $\mathrm{CO}_{2}$-emissie of -vastlegging te bepalen, zodat het gebruikt kan worden voor het monitoren van de realiseerbare bijdrage aan de klimaatdoelstelling voor slim landgebruik.

De eisen waaraan een praktijkmodel moet voldoen, zijn opgesteld en de geschiktheid van twaalf koolstofmodellen is geïnventariseerd. Uit deze inventarisatie zijn vier potentiële praktijkmodellen geselecteerd: Century, CCB, NDICEA en RothC. Deze modellen zijn getest aan de hand van twee lange-termijndatasets, namelijk vanuit de 'Mest als Kans' (MAK) proef (Rietberg en Van der Burgt, 2012) en vanuit een aantal proefvelden van proefboerderij Vredepeel. Century is tijdens deze test afgevallen als praktijkmodel vanwege de complexiteit en de verouderde software, die geautomatiseerd runnen moeilijk maakt. De andere drie modellen hebben voor- en nadelen en zijn meer of minder geschikt voor het doorrekenen van bepaalde bodem C-maatregelen.

Gedurende dit project is duidelijk geworden dat er op dit moment nog niet voor één model gekozen moet worden als praktijkmodel. De keuze voor welk model te gebruiken als praktijkmodel hangt af van de beoogde toepassing. Wanneer het model alleen voor monitoring van bodem $\mathrm{C}$ geschikt moet zijn, zou RothC een logische keuze zijn, aangezien de inputdata makkelijk te verkrijgen zijn in de praktijk, de code gemakkelijk aan te passen is en grote datasets (veel percelen) doorgerekend kunnen worden. Als het doel gericht is op advisering van boeren zou juist NDICEA geschikter zijn, omdat het meer indicatoren (en met hogere temporele resolutie) kan leveren op en ook interacties met stikstof (en fosfaat) bemesting meeneemt. CCB heeft een bepaald gebruikersgemak als voordeel; ook door mensen met weinig kennis van het model kunnen maatregelen om bodem $C$ te verhogen, worden ingevoerd.

Om beter inzicht te krijgen in het functioneren van de verschillende modellen zou het goed zijn om deze modellen te testen op één of meer langetermijndatasets. Aangezien deze binnen Nederland zeer beperkt beschikbaar zijn, zou ook gebruikgemaakt kunnen worden van data uit omliggende landen. Een alternatief is het gebruiken van een fictief proefveld met klassieke akkerbouwrotatie (tarwe, bieten, aardappelen), aangezien de nu gebruikte testdatasets niet de standaard akkerbouwrotatie hebben. De volgende stap is daarna om de software van het praktijkmodel geschikt te maken voor toepassing, het praktijkmodel te testen op bedrijven binnen de pilots van het 'Slim Landgebruik'programma en maatregelen door te rekenen voor de voorgestelde bodem C-maatregelen. 


\section{$1 \quad$ Introductie}

\subsection{Achtergrond}

In 2017 heeft het kabinet in het regeerakkoord reductiedoelstellingen voor broeikasgasemissies opgenomen. De landbouw- en landgebruikssector moet in 2030 een bijdrage leveren van 3,5 Mton $\mathrm{CO}_{2}$ per jaar; hiervan is 1,5 Mton opgenomen voor slim landgebruik. In het Klimaatakkoord dat in juni 2019 is gepresenteerd, is dit verder uitgewerkt en is een reductiedoelstelling voor landbouwbodems opgenomen van 0,5 Mton $\mathrm{CO}_{2}$ per jaar in 2030. Dit betekent dat er in Nederland gemiddeld per hectare landbouwgrond ongeveer $500 \mathrm{~kg} \mathrm{CO}_{2}$ (ofwel $125 \mathrm{~kg}$ koolstof) extra per jaar in de bodem moet worden vastgelegd. Om de bijdrage die de bodem kan leveren aan het vastleggen van koolstof (C) te bepalen, is het belangrijk om de bijdrage van maatregelen die C-vastlegging bevorderen te kwantificeren.

Voor het kwantificeren van vastlegging (of verliezen) van organische koolstof in de bodem zijn metingen over langere tijd nodig, omdat het meestal een relatief langzaam proces betreft waarin op korte termijn slechts kleine veranderingen optreden ten opzichte van een grote voorraad. Om een goed beeld te krijgen van de koolstofvoorraad, is inzicht in de ruimtelijke en temporele variabiliteit noodzakelijk. Het nemen en analyseren van bodemmonsters is echter een kostbaar proces, wat het monitoren van de koolstofvoorraad belemmert. Daarnaast is het direct bepalen van de effecten van bodem C-maatregelen lastig, omdat het aantal boeren dat maatregelen heeft geïmplementeerd gering is, er praktische variatie bestaat in hoe en waar dit precies wordt gedaan en omdat langetermijnmetingen ontbreken. Het alternatief is om veranderingen in de koolstofvoorraad in te schatten met behulp van simulatiemodellen. Momenteel zijn er veel koolstofmodellen beschikbaar, maar niet elk model is geschikt als praktijkmodel. Het praktijkmodel moet namelijk geschikt zijn om voor Nederlandse landbouwbedrijven met grasland en/of bouwland koolstofvoorraden te kwantificeren, veranderingen in C-voorraad te simuleren en het effect van bodem C-maatregelen te schatten.

Deze studie vergelijkt en beoordeelt beschikbare bodem C-modellen met als doel één of meerdere modellen te identificeren als praktijkmodel. Het praktijkmodel zou op langere termijn kunnen worden uitgebouwd tot een Decision Support Tool, waarmee boeren het effect van bodem C-maatregelen kunnen analyseren en afwegen. Het is van belang dat de uitkomsten met de praktijktool aansluiten bij de nationale emissieregistratie of uiteindelijk zelfs gebruikt kunnen worden om mitigatie-inspanningen zichtbaar te maken in de emissieregistratie en mee te laten tellen voor de nationale reductiedoelstelling. Het praktijkmodel moet daarmee bijdragen aan het bereiken van de mitigatiedoelstelling van 1,5 Mton voor slim(mer) landgebruik.

Dit project sluit aan op het lopende Topconsortia voor Kennis en Innovatie (TKI) project 'Belang van vastlegging van koolstof in de bodem voor mitigatie van broeikasgassen', waarin Wageningen Research samen met FrieslandCampina werkt aan de ontwikkeling van een bodem C-module om koolstofvastlegging in minerale landbouwbodems en $\mathrm{CO}_{2}$-emissies uit veengronden op bedrijfsniveau te bepalen voor de melkveehouderij.

\subsection{Doelstelling}

Het doel van deze studie is om vanuit bestaande C-modellen één of meerdere praktijkmodellen te identificeren voor het kwantificeren van de koolstofvoorraad in minerale landbouwbodems op perceelen bedrijfsniveau en het simuleren van veranderingen in de koolstofvoorraad onder huidig of alternatief bodembeheer. Het praktijkmodel moet toepasbaar zijn in Nederlandse condities, zich lenen voor opschaling en bodem $\mathrm{C}$-maatregelen door kunnen rekenen om de netto $\mathrm{CO}_{2}$-emissie of -vastlegging te bepalen, zodat het gebruikt kan worden voor het monitoren van de realiseerbare bijdrage aan de klimaatdoelstelling voor slim landgebruik. 


\subsection{Aanpak}

Voor de ontwikkeling van het praktijkmodel zijn verschillende stappen doorlopen. Er is eerst in samenwerking met stakeholders uit de sector en onderzoekers die bodemkoolstof modelleren een programma van eisen opgesteld voor een praktijkmodel. Aspecten die we in acht hebben genomen tijdens het opstellen van het programma van eisen, zijn o.a. de bruikbaarheid en toepassing van het te ontwikkelen praktijkmodel voor nationale emissieregistratie, de (beperkte) beschikbare data van bedrijven en de koppeling met bestaande gebruiks- en bodemdata van bedrijven. Tevens is er een selectie gemaakt van de maatregelen die het model door moet kunnen rekenen.

Vervolgens is er een inventarisatie uitgevoerd van bestaande modellen die mogelijk geschikt zijn als praktijkmodel. Tijdens deze inventarisatie is er gekeken naar modellen met een uiteenlopende complexiteit; van een simpele organische stofbalanstool, zoals de OS-tool van het NMI, tot complexe procesmodellen als Century. Voor de modellen die voldeden aan de gestelde eisen is er gekeken welke data er ten minste nodig zijn om het model op perceel- en bedrijfsniveau te kunnen gebruiken. De inputdata van de geselecteerde modellen omvatten o.a. data over bodem, weer, bedrijfsmanagement, bemesting en gewasopbrengst.

Op basis van de gestelde eisen worden de geschiktste modellen getest aan de hand van twee langetermijndatasets, namelijk vanuit de 'Mest Als Kans' (MAK) proef en een aantal proefvelden van proefboerderij Vredepeel. Voor het vervolg van deze studie zullen de modellen ook nog worden getest op een aantal praktijkbedrijven die meedoen aan de pilots in het Slim Landgebruik-programma. Met behulp van de daar opgedane ervaring zal samen met de sector en het ministerie van LNV besloten worden hoe een praktijkmodel zal worden geïmplementeerd. Hiervoor zal het model omgezet worden naar een geschikte softwareomgeving, met koppeling aan bestaande datasystemen en een toegankelijke gebruiksomgeving. 


\section{Programma van eisen}

In samenspraak met het ministerie van LNV en de stakeholders die deelnemen aan het Slim Landgebruik Programma is besloten om in dit project - voor de periode 2018/2019 - de focus te leggen op het zoeken naar een praktijkmodel dat geschikt is voor het schatten van veranderingen in bodem $\mathrm{C}$ onder onveranderd of alternatief bodembeheer. In een later stadium kan het praktijkmodel mogelijk verder worden ontwikkeld als Decision Support Tool. Om een geschikt praktijkmodel te ontwikkelen, is het belangrijk om de behoefte van de gebruikers duidelijk in beeld te hebben. Daarom is er in samenwerking met het ministerie, onderzoekers en andere stakeholders een programma van eisen opgesteld waarin naar voren komt wat het model moet bieden en aan welke criteria het idealiter moet voldoen. Hierbij zijn onderstaande aspecten genoemd die voor de ontwikkeling van het praktijkmodel in acht genomen zijn. Het model moet:

- Een organische stof (OS)-balans op perceelniveau kunnen uitrekenen op basis van de aanvoer en afbraak van organische stof in de bodem.

- Afbraak van organische stof kunnen simuleren, waarbij rekening wordt gehouden met bodemtype, gewas en klimaat.

- Passen in een monitoringsinstrument dat gebruikt wordt (of kan worden) bij de berekening van de broeikasgasemissies in ketenanalyses.

- Bruikbaar zijn en aansluiten bij de nationale emissieregistratie.

- Effecten van bodemmaatregelen kunnen simuleren, waaronder verandering in aanvoer organische stof, aanpassing in rotaties en mate van grondbewerking.

- Een databehoefte hebben die past bij de (beperkte) beschikbare data van bedrijven en mogelijkheid voor koppeling met bestaande bedrijfsmanagement- en bodemdatasystemen.

- Inzichtelijke resultaten leveren voor gebruikers (boeren, maar ook organisaties en ketenpartijen die bij monitoring betrokken zijn).

- De mogelijkheid hebben voor koppeling van koolstofdynamiek met mogelijke afwenteling op $\mathrm{N}_{2} \mathrm{O}$ emissies. 


\section{Analyse bestaande koolstofmodellen}

\subsection{Keuze modellen}

Om te onderzoeken welke bestaande bodemkoolstofmodellen en tools geschikt zijn voor het praktijkmodel, hebben we een lijst opgesteld met modellen die frequent worden toegepast in onderzoek alsook in de praktijk. Bij de eerste inventarisatie is gekeken naar:

- Organische stof (OS) balans tools (bijv. OS-tool NMI)

- Modellen gebaseerd op de 'stock change approach' van de IPCC (bijv. Cool Farm Tool)

- Dynamische koolstofmodellen (bijv. Roth-C, NDICEA, EPIC, ORCHIDEE, CCB)

- Procesmodellen (bijv. CANDY, DayCent, Century, DNDC, EPIC)

Hieronder staat een korte beschrijving van de verschillende modellen. Meer informatie over de modellen is te vinden in Bijlage 1.

\subsubsection{CANDY}

Het CANDY-model is opgebouwd uit meerdere modules en is ontwikkeld om koolstof- en stikstofdynamiek van landbouwbodems te simuleren. Het model is gebaseerd op langetermijnexperimenten en kan gebruikt worden om dagelijkse veranderingen in water, temperatuur, koolstof en stikstof in de bodem te berekenen. Hiermee kunnen landbouwbedrijven kortetermijnvariaties in bodemstikstof bepalen. Daarnaast bevat het model ook een koolstofmodule waarmee langetermijnveranderingen in de koolstofvoorraad in de bodem berekend kunnen worden. Deze zijn afhankelijk van aanvoer van organisch materiaal, bodemstructuur, klimaat en bedrijfsmanagement (Franko et al., 1995).

\subsubsection{CANDY Carbon Balance (CCB)}

Het CANDY Carbon Balance (CCB) model is een versimpelde versie van de bodemkoolstofmodule van CANDY, met een lagere databehoefte. CCB is ontwikkeld om jaarlijkse veranderingen in organischestofgehalte van landbouwbodems te simuleren. Dit kan op perceelniveau, maar ook op grote schaal, zoals regionaal of landelijk. De jaarlijkse verandering in koolstof is afhankelijk van temperatuur, neerslag, irrigatie, gewasopbrengst, aanvoer van vers organisch materiaal, bodemstructuur, en het initiële organisch stofgehalte van de bodem (Franko et al., 2011). Voor simulaties op perceelniveau kunnen gegevens handmatig ingevoerd worden. Voor simulaties van grotere gebieden kunnen middels de zogenaamde batch-mode eenvoudig grote hoeveelheden data ingevoerd worden.

\subsubsection{Century}

Het procesmodel Century 4.6 kan gebruikt worden om de koolstof- en nutriëntendynamiek te simuleren voor verschillende soorten ecosystemen, waaronder graslanden, landbouwgronden, bossen en savannes. Voor de grasland-, gewas- en bossystemen zijn er verschillende modules voor de productie van planten die gekoppeld zijn aan een gemeenschappelijk bodemorganische stof-module. De organische stof-module simuleert de stroming van C, N, P en S door plantenafval en de verschillende anorganische en organische compartimenten in de bodem (Parton et al., 1992).

\subsubsection{Cool Farm Tool}

De Cool Farm Tool 2.0 is een decision-support tool, ontwikkeld door de Cool Farm Alliance. Deze tool is bedoeld voor boeren en de voedselverwerkende industrie om gezamenlijk aan klimaatdoelstellingen te werken en verbeteringen in de voedselketen te realiseren. Het kan onder andere gebruikt worden om de $\mathrm{CO}_{2}$-footprint bij het verbouwen van gewassen te berekenen. In de online rekentool worden 
gegevens ingevoerd voor bijvoorbeeld het gewas, de opbrengst, het kunstmestverbruik, de landbewerking en oogstmethode. De tool bepaalt vervolgens de $\mathrm{CO}_{2}$-footprint van het geteelde gewas. Op deze manier kunnen scenario's worden berekend om te bepalen wat verstandige keuzes zijn om zo de milieu-impact in de voedselketen te beperken (Hillier et al., 2011).

\subsubsection{DayCent}

DayCent 4.5 is een biogeochemisch model dat in staat is om groei van gewassen, koolstofdynamiek, $\mathrm{N}$-uitspoeling, gasvormige emissies (bijv. $\mathrm{N}_{2} \mathrm{O}, \mathrm{NO}, \mathrm{N}_{2}, \mathrm{NH}_{3}, \mathrm{CH}_{4}$ en $\mathrm{CO}_{2}$ ) en koolstoffluxen te simuleren in akkerbouwgewassen, graslanden, bossen en savanne-ecosystemen. Het model kan ook gebruikt worden om verschillende managementpraktijken te simuleren (bijv. bemesting, grondbewerking, snoeien, snijden, begrazen etc.), evenals specifieke externe verstoringen (bijv. brand) (Parton et al., 1998). Het model is een uitgebreide versie van het Century-model.

\subsubsection{DeNitrification-DeComposition (DNDC)}

Het DeNitrification-DeComposition (DNDC 9.5) model is een procesmodel voor koolstof en stikstof biogeochemie in de landbouw bodems. Het model bevat vier modules en kan gebruikt worden om gewasgroei, bodemtemperatuur, bodemkoolstofdynamiek, $\mathrm{N}$-uitspoeling en emissies van lachgas $\left(\mathrm{N}_{2} \mathrm{O}\right)$, stikstofmonoxide $(\mathrm{NO})$, stikstof $\left(\mathrm{N}_{2}\right)$, ammoniak $\left(\mathrm{NH}_{3}\right)$, methaan $\left(\mathrm{CH}_{4}\right)$ en koolstofdioxide $\left(\mathrm{CO}_{2}\right)$ te berekenen ( $\mathrm{Li}$ et al., 1994).

\subsubsection{EPIC}

Het Environmental Policy Impact Climate (EPIC) 08.10 model is ontwikkeld om de invloed van bodemerosie op bodem productiviteit in de Verenigde Staten te bepalen (Izaurralde et al., 2006). Het EPIC-model bestaat uit meerdere componenten om erosie, plantengroei en gerelateerde processen te simuleren. Het bevat ook economische componenten om de kosten van erosie en de effecten van managementmaatregelen door te rekenen. De nieuwste versie van EPIC bevat ook een koolstofmodule die gebaseerd is op het Century model (Parton en Rasmussen, 1994).

\subsubsection{NDICEA}

NDICEA 6.2 is een dynamisch model ontwikkeld om effecten van afbraak van koolstof en nalevering van stikstof door verschillen in landbouwmanagement (rotatie, bemesting etc.) weer te geven op perceelniveau (Van der Burgt et al., 2006). NDICEA is opgebouwd uit verschillende modules voor gewas, water en bodem. Van de drie modules is de bodemmodule het uitgebreidst. Deze module bevat zowel een koolstofafbraak-model als een stikstofflux-model. Het model is gemaakt om boeren praktisch inzicht en advies te kunnen geven. Metingen van $\mathrm{N}$-mineraal op verschillende dieptes in de bodem, en C-organisch, kunnen worden gebruikt ter validatie van berekeningen.

\subsubsection{ORCHIDEE}

ORCHIDEE 2.0 is een dynamisch vegetatiemodel, ontwikkeld door Institut Pierre Simon Laplace (IPSL). Het simuleert de uitwisseling van water, koolstof en energie tussen het aardoppervlak en de atmosfeer. Het model kan gekoppeld worden aan een global climate model om interactie van vegetatie en landgebruik met het klimaat te simuleren. De bodemmodule van dit model is vergelijkbaar met die van Century (Krinner et al., 2005).

\subsubsection{OS balans NMI}

OS Balans NMI 1.2.0 is een simpele, gebruikersvriendelijke rekentool ontwikkeld voor bedrijven in de akkerbouw, vollegrondsgroenteteelt en de boomkwekerij (NMI, 2014). Met deze tool kan de organische stof-balans van landbouwbedrijven berekend worden. De organische stof-balans is gebaseerd op de aan- en afvoer van organisch materiaal. In deze tool wordt ook rekening gehouden met de afbraak van organische stof in de bodem. 


\subsubsection{OS-balans Productschap Akkerbouw}

De OS-balans tool van het productschap akkerbouw is ontwikkeld als hulpmiddel voor akkerbouwers bij organische stofbeheer op hun bedrijf (Zwart et al., 2013). Met deze tool kunnen de OS-balans en stikstofmineralisatie per teeltrotatie op een eenvoudige manier worden berekend. De OS-balans wordt bepaald aan de hand van het Effectieve Organische Stof (EOS) gehalte in gewasresten, groenbemesters en organische meststoffen en de natuurlijke afbraak van bestaande organisch stof in de bodem. De natuurlijke afbraak wordt berekend als functie van organischestofgehalte. De balans van EOS en natuurlijke afbraak geeft inzicht in de verandering van het OS-gehalte in de bodem.

\subsubsection{RothC}

RothC-26.3 is een dynamisch model voor afbraak van koolstof in de bodem. Het model is ontwikkeld om de koolstofdynamiek in minerale bodems te simuleren en houdt rekening met de effecten van temperatuur, neerslag, verdamping, kleigehalte en bodembedekking. Het kan gebruikt worden om veranderingen in bodemorganische stof-gehalte te simuleren met behulp van vooraf bekende inputgegevens, maar ook om de inputgegevens te bepalen als de veranderingen in bodemorganische stof bekend zijn. RothC is gekalibreerd op data van langetermijnexperimenten uit Rothamsted. Het was in eerste instantie ontwikkeld voor akkerland, maar het model is later uitgebreid, zodat het ook voor grasland en bosbouw gebruikt kan worden. Het model is veelvuldig getest en gevalideerd, maar het vereist voor elke situatie een aparte initialisatie en validatie. Het model wordt gebruikt op verschillende schaalniveaus, variërend van plot tot wereldschaal, met data van langetermijnexperimenten uit verschillende regio's en landen (Coleman and Jenkinson, 1996).

\subsection{Criteria voor beoordeling}

Modeleigenschappen en selectiecriteria dragen bij aan de geschiktheid van een model als praktijktool. De twaalf modellen zijn uitgebreid geïnventariseerd. Een overzicht van deze inventarisatie is weergegeven in Tabel 1.

Er is een aantal criteria opgesteld die de keuze van een model als potentiële praktijktool beïnvloeden:

- Idealiter is het model wetenschappelijk gepubliceerd en toegepast in wetenschappelijke studies.

- Idealiter is het model publiekelijk beschikbaar, heeft het een licentie voor commercieel gebruik en is de Application Programming Interface (API) beschikbaar.

- Het moet mogelijk zijn om de broncode van het model te verifiëren en aan te passen.

- Idealiter is het model gevalideerd en toegepast in gebieden vergelijkbaar met Nederland.

- De benodigde inputparameters moeten beschikbaar (of makkelijk te verkrijgen) zijn.

- Idealiter heeft het model meerdere outputparameters en niet alleen C.

- Het model moet bodemorganische stof dynamisch of procesmatig simuleren.

- Het model moet op perceel- en bedrijfsniveau kunnen fungeren.

- Het model moet bodem C-maatregelen door kunnen rekenen. 


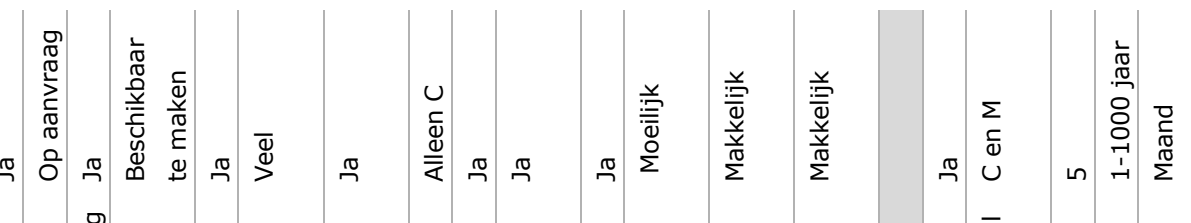

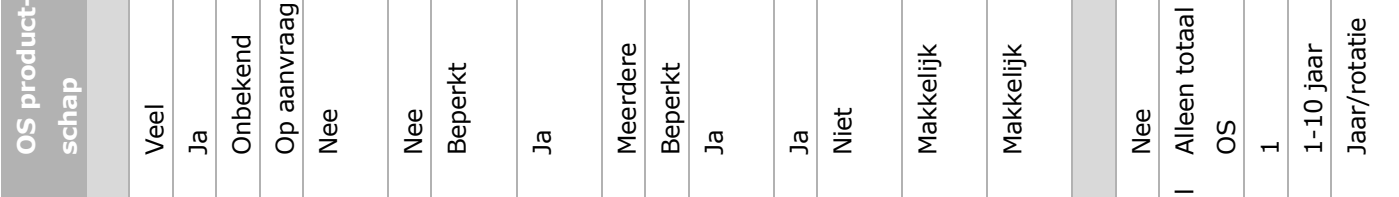

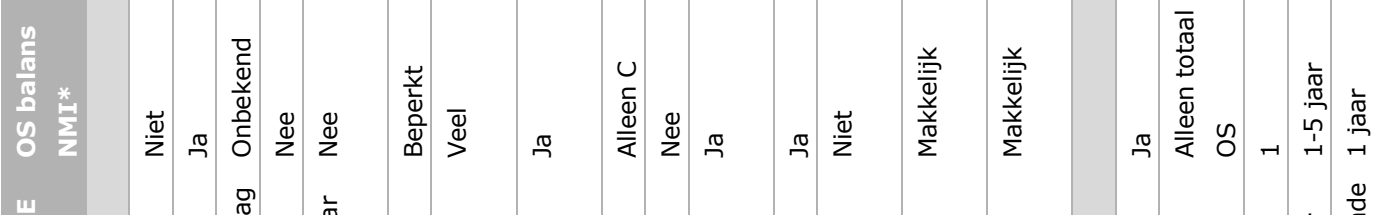

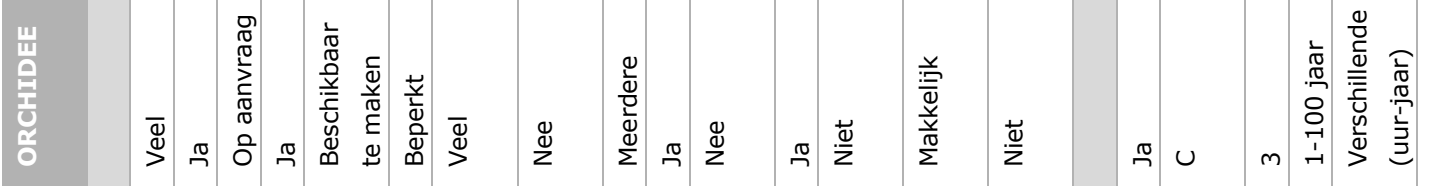

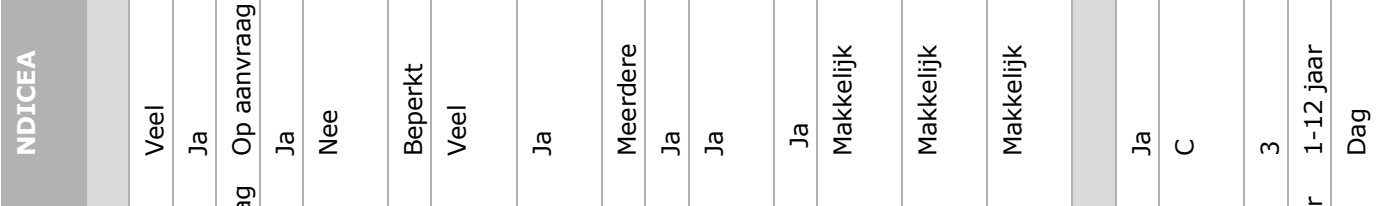

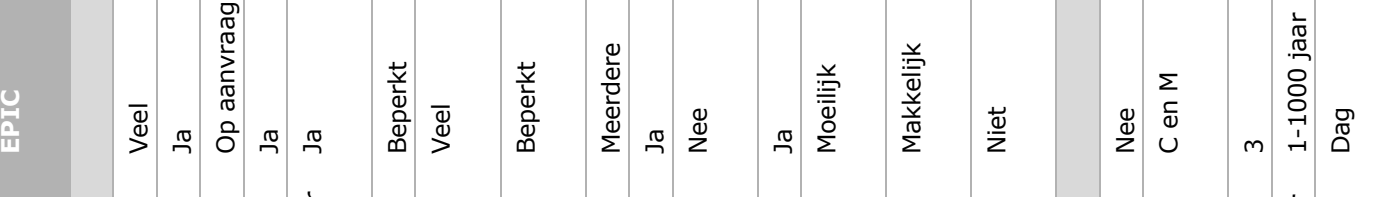

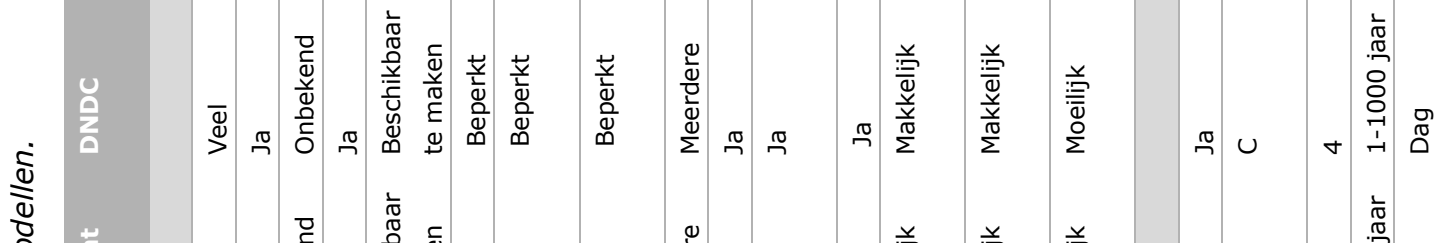

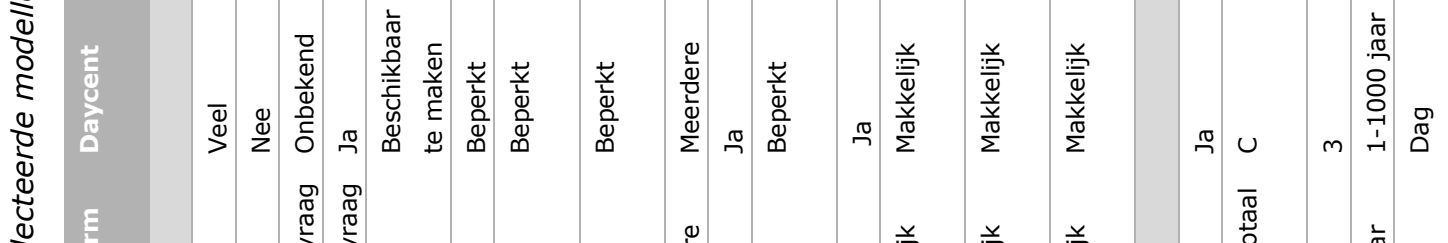

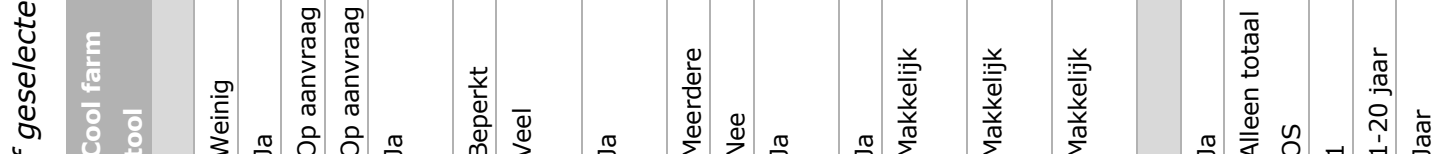

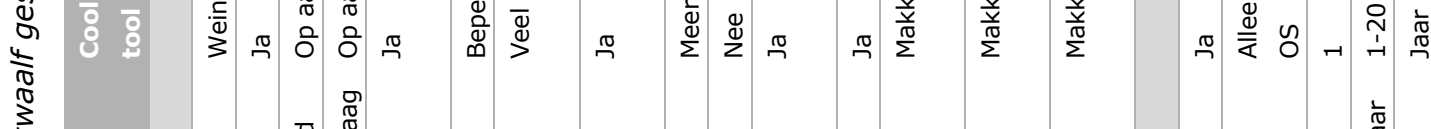

ป

$\frac{1}{8}$

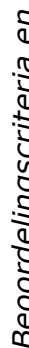

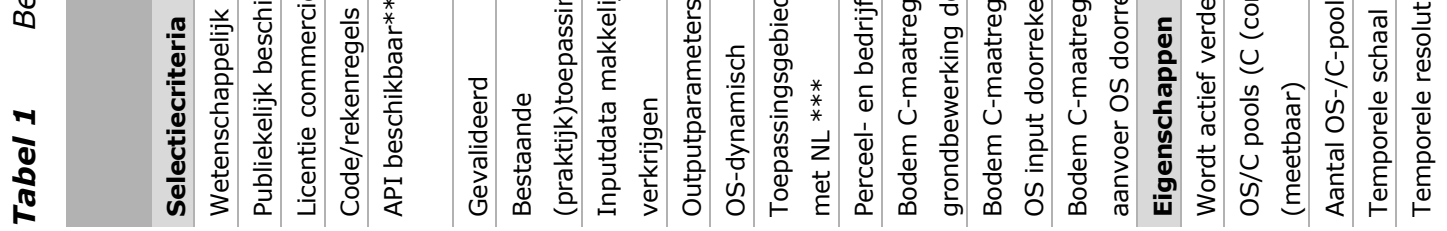




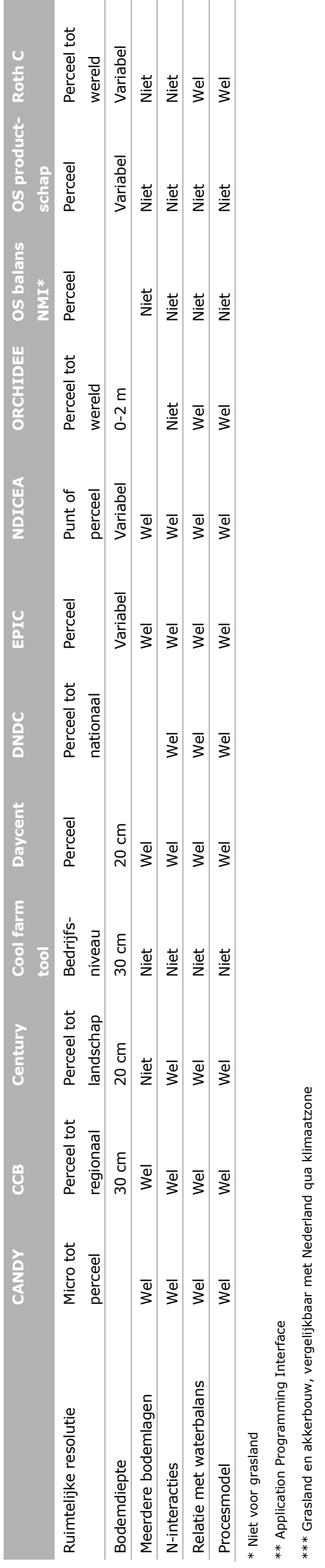

Wageningen Environmental Research Rapport 2990 | 16 


\subsection{Resultaat analyse}

Om uiteindelijk tot een selectie van geschiktste modellen te komen, hebben we gekeken welke modellen voldoen aan de selectiecriteria. Op basis hiervan zijn we tot een selectie gekomen van vier modellen: Century, RothC, CCB en NDICEA.

Deze vier modellen zijn wetenschappelijk gepubliceerd, publiekelijk beschikbaar en hebben een beschikbare broncode. Verder kunnen deze vier modellen de meeste bodem C-maatregelen doorrekenen en is de OS-balans dynamisch geïmplementeerd. De inputdata zijn makkelijk te verkrijgen voor CCB en RothC, maar moeilijker voor Century. NDICEA kan met makkelijk verkrijgbare data rekenen, maar het kan met moeilijker verkrijgbare data meer detail bieden (met name op de stikstofdynamiek).

De modellen CANDY, DNDC, Daycent, EPIC en ORCHIDEE zijn niet gekozen, aangezien deze modellen veel inputdata en veel kennis vereisen, en daarmee niet geschikt zijn als praktijkmodel. De modellen zijn meer geschikt voor toepassing in onderzoek. De OS-balanstool van NMI en die van Productschap Akkerbouw zijn daarentegen wel ontwikkeld als praktijktool, maar kunnen minder goed de bodem C-dynamiek simuleren en nemen het effect van bodemtype en klimaat niet mee. Daarnaast zijn deze tools ook minder geschikt voor het doorrekenen van de effecten van een aantal bodem $\mathrm{C}$-maatregelen. Aanpassingen in de broncode zijn nodig om deze modellen geschikter te maken als praktijkmodel.

De Cool Farm Tool is uiteindelijk niet meegenomen, aangezien dit model bodem $\mathrm{C}$ op een andere manier simuleert. Het model simuleert bodem $\mathrm{C}$ met behulp van de stock change approach van de IPCC en het werkt met grove klassen van bodem C. Daardoor kan het model niet goed bodem C-veranderingen over tijd simuleren. De Nederlandse akkerbouwsector heeft nu echter wel voorgesteld om de Cool Farm Tool te gebruiken voor het berekenen van de Carbon Footprint van de teelt van gewassen. De Cool Farm Tool is hier zeker geschikt voor en heeft gedetailleerde berekeningen voor de emissies van $\mathrm{N}_{2} \mathrm{O}$ en $\mathrm{CO}_{2}$ uit energie, maar voor monitoring van bodem $\mathrm{C}$-veranderingen is het dus minder geschikt. Mogelijk zou in de toekomst ook een meer proces gebaseerd model voor bodem $\mathrm{C}$ gekoppeld kunnen worden aan de Cool Farm Tool. IPCC heeft hiervoor recentelijk een nieuwe tool gelanceerd (Buendia et al., 2019). Deze tool werd gelanceerd en gepubliceerd nadat deze studie was uitgevoerd. Vandaar dat we dit niet meegenomen hebben in onze analyse. 


\section{Databehoefte modellen}

De vier geschiktste koolstofmodellen hebben verschillende databehoeften. De databehoefte is afhankelijk van het doel van het model en de complexiteit van het model. Uit Tabel 1 kwam naar voren dat de inputdata voor RothC en CCB makkelijker te verkrijgen zijn dan de inputdata voor Century. NDICEA kan zowel met een beperkte als met een uitgebreide dataset rekenen. Als we de modellen gaan testen, zal NDICEA met een uitgebreide dataset rekenen. De databehoefte kan opgesplitst worden in noodzakelijke en optionele inputparameters. Voor de vier koolstofmodellen zijn deze noodzakelijke inputparameters gegeven in Tabel 2.

Klimaatdata kunnen verkregen worden via het KNMI en hoeven dus niet apart door de gebruiker te worden aangeleverd. Andere inputdata moeten verkregen worden uit bestaande databases of aan de hand van metingen.

Tabel 2 Noodzakelijke input parameters voor de vier geselecteerde modellen (lege cellen betekent dat het model deze parameter niet gebruikt).

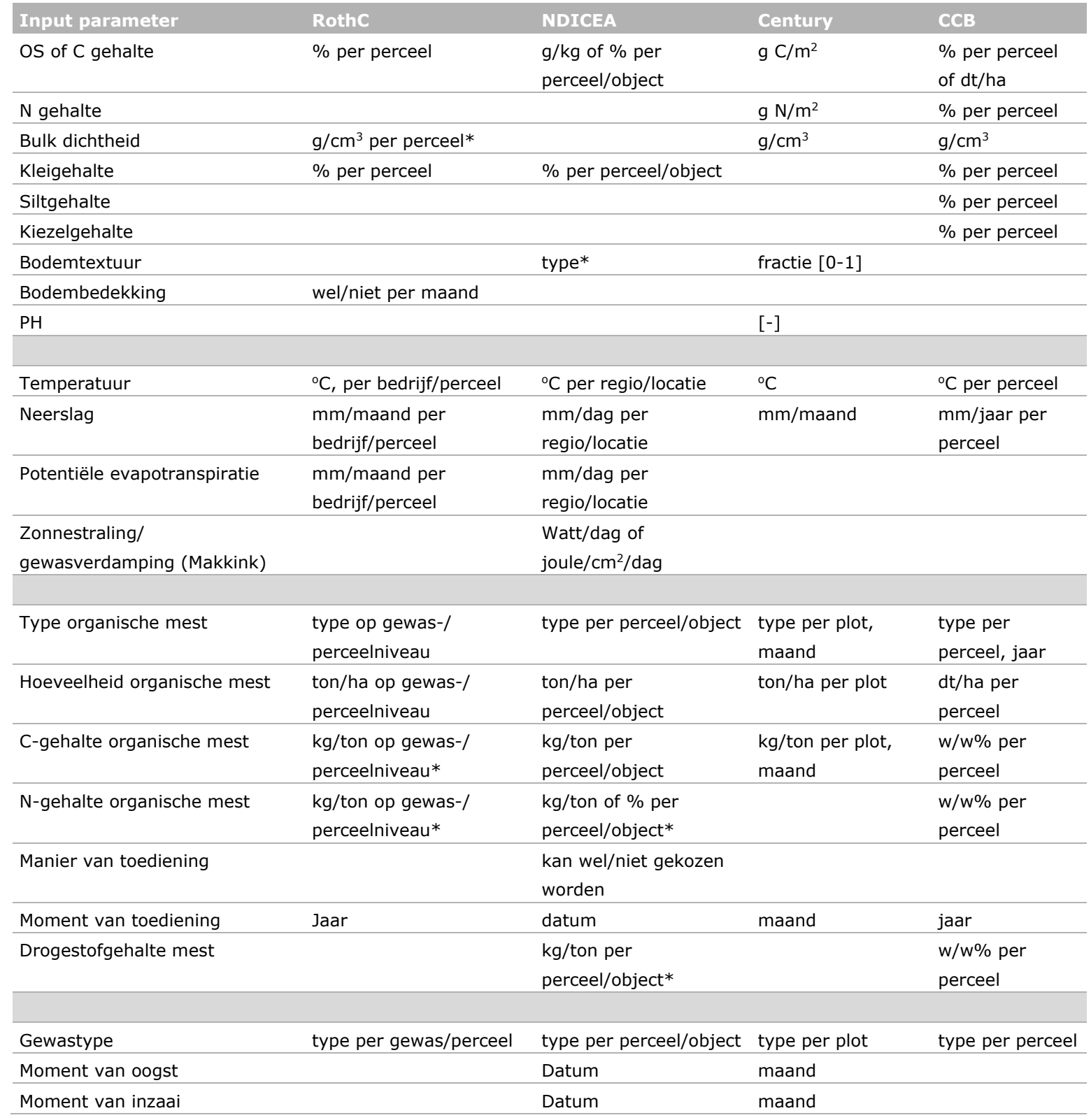




\begin{tabular}{|c|c|c|c|c|}
\hline Input parameter & RothC & NDICEA & Century & $\mathrm{CCB}$ \\
\hline Opbrengst & $\begin{array}{l}\mathrm{kg} / \text { ha per gewas en } \\
\text { perceel }\end{array}$ & $\begin{array}{l}\text { ton/ha per } \\
\text { perceel/object }\end{array}$ & & $\begin{array}{l}\mathrm{dt} / \text { ha per } \\
\text { perceel }\end{array}$ \\
\hline Harvest index & {$[-]$ per gewas } & & & \\
\hline Opbrengst gewasresten & $\begin{array}{l}\mathrm{kg} / \text { ha per gewas en } \\
\text { perceel } *\end{array}$ & $\begin{array}{l}\text { ton/ha per } \\
\text { perceel/object* }\end{array}$ & & $\begin{array}{l}\mathrm{dt} / \text { ha per } \\
\text { perceel }\end{array}$ \\
\hline Afvoer gewasresten & $\begin{array}{l}\mathrm{kg} / \text { ha per gewas en } \\
\text { perceel }\end{array}$ & & & $\begin{array}{l}\mathrm{dt} / \text { ha per } \\
\text { perceel }\end{array}$ \\
\hline Moment afvoer gewasresten & & datum & & \\
\hline Moment van irrigatie & maand per perceel* & datum & maand & jaarbasis \\
\hline Hoeveelheid & $\mathrm{mm} / \mathrm{maand}$ per perceel* & $\begin{array}{l}\text { mm/dag per } \\
\text { perceel/object }\end{array}$ & $\begin{array}{l}\text { intensiteit per plot, } \\
\text { maand }\end{array}$ & $\begin{array}{l}\mathrm{mm} / \mathrm{jaar} \text { per } \\
\text { perceel }\end{array}$ \\
\hline $\mathrm{N}$-gehalte irrigatie water & & $\mathrm{mg} / \mathrm{L}^{*}$ & & $\mathrm{~g} / \mathrm{L}$ \\
\hline Beweiding & $\%$ per perceel/bedrijf & & $\begin{array}{l}\text { intensiteit per plot, } \\
\text { maand }\end{array}$ & per perceel \\
\hline Soortensamenstelling grasland & & per perceel of bedrijf & & per perceel \\
\hline Scheuren & $\%$ per perceel/bedrijf & $\begin{array}{l}\text { datum per } \\
\text { perceel/bedrijf }\end{array}$ & & per perceel \\
\hline Maaidatum & & $\begin{array}{l}\text { datum per } \\
\text { perceel/bedrijf }\end{array}$ & & \\
\hline Grondbewerking & $\begin{array}{l}\text { type per gewas of } \\
\text { perceel }\end{array}$ & $\begin{array}{l}\text { intensiteit per } \\
\text { perceel/object }\end{array}$ & intensiteit per plot & per perceel \\
\hline
\end{tabular}

In het project 'Ontsluiting van en koppeling aan praktijkdata over bodemgebruik en bodemmanagement', project 1.7 van het Slim Landgebruik Programma, is gekeken in hoeverre deze benodigde inputdata, zoals weergegeven in Tabel 2, beschikbaar zijn in bestaande databronnen, waaronder landbouwtelling, Kringloopwijzer, Teeltcentraal en het Bedrijven Informatienetwerk. Uit de analyse kwam naar voren dat geen enkele databron alle benodigde data voor de modelsimulaties bevat. Evenwel is het merendeel van de benodigde data uit een combinatie van datasets te halen (Smit et al., 2019). Een deel van de data over bodembeheer maatregelen bleek te ontbreken of niet op het juiste detailniveau aanwezig te zijn. Verdere informatie over deze analyse kan gevonden worden in het rapport van Smit et al. (2019). 


\section{$5 \quad$ Kwantitatieve vergelijking modellen}

Naast de kwalitatieve vergelijking van de modellen, zoals beschreven in de vorige hoofdstukken, zijn de geselecteerde koolstofmodellen ook kwantitatief met elkaar vergeleken op basis van datasets van twee langetermijnexperimenten. Dit levert inzicht in de vergelijkbaarheid van de modellen en de geschiktheid voor toepassing onder Nederlandse omstandigheden op basis van data uit deze praktijkproeven. Voor deze studie zijn de data van proeflocatie MAK en van proefboerderij Vredepeel geselecteerd.

Het model Century bleek tijdens het testen van de modellen niet correct te functioneren vanwege de complexiteit en de verouderde software, die automatiseren voor meerdere percelen niet mogelijk maakte. Aanpassingen in de interface van het model zijn noodzakelijk om het toe te kunnen passen. Century is daarom alsnog afgevallen als potentieel praktijkmodel en zal niet verder meegenomen worden in de kwantitatieve analyse.

\subsection{Beschrijving testdataset}

\subsubsection{Proeflocatie Mest Als Kans in Lelystad}

De proeflocatie van MAK in Lelystad is een van de langstlopende proeflocaties van Nederland (sinds 1999). De boerderij is gelegen ten noorden van Lelystad en het kleigehalte van de bodem varieert tussen de 9 en 9,75\%. De proef is aangelegd met dertien typen bemesting in vier herhalingen. In deze studie focussen we op vier typen bemesting, namelijk: NPK, rundveedrijfmest, groente-, gruit-, en tuinafvalcompost ( $\mathrm{gft}$ ) en potstalmest. Voor deze studie gebruiken we de OS-gehaltes die in 2007 en 2016 gemeten zijn in de bodem op $25 \mathrm{~cm}$ diepte. In 2007 lag het OS-gehalte in de laag 0-30 cm tussen de 1,5 en $1,7 \%$ en in 2016 tussen de 1,7 en 2,1\%. Uit de metingen blijkt dat het uitsluitend gebruiken van gft op termijn kan leiden tot lagere opbrengsten. Hetzelfde geldt voor het uitsluitend gebruiken van NPK (Bloem et al., 2017). Op alle percelen wordt van 2011 t/m 2013 en van 2015 t/m 2017 naast NPK, drijfmest, gft of potstalmest ook een groenbemester geteeld na de oogst van het hoofdgewas. De groenbemester en de gewasresten die overblijven na de oogst van het hoofdgewas worden in de bodem ondergewerkt.

Tabel 3 Organische mestgiften (ton vers) voor vier verschillende behandelingen in de proeflocatie 'Mest als Kans' in Lelystad.

\begin{tabular}{|c|c|c|c|c|c|}
\hline Jaar & Gewas & NPK & Drijfmest & Gft & Potstalmest \\
\hline 2007 & Aardappel & 0 & 0 & 0 & 0 \\
\hline 2008 & Schorseneer & 0 & 39,5 & 18,9 & 40,5 \\
\hline 2010 & Pompoen & 0 & 0 & 0 & 0 \\
\hline 2011 & Pastinaak & 0 & 40,5 & 9,2 & 35,4 \\
\hline 2013 & Schorseneer & 0 & 0 & 0 & 0 \\
\hline 2014 & Prei & 0 & 38,6 & 9,7 & 31,4 \\
\hline 2015 & Suikermais & 0 & 38,6 & 9,7 & 31,4 \\
\hline 2016 & Schorseneer & 0 & 0 & 0 & 0 \\
\hline
\end{tabular}




\subsubsection{Proeflocatie Vredepeel}

Proefboerderij Vredepeel is gelegen in het Limburgse Vredepeel. Deze jonge ontginningsgrond had aan het begin van het experiment een OS-gehalte in de bodem voor de laag 0-30 cm tussen de 3,6 en $4,4 \%$, waarbij het kleigehalte lager is dan $1 \%$. De proefboerderij onderscheidt drie typen bemesting: 1) biologisch bemesting waarbij rundveedrijfmest, vaste rundermest en Vinassekali toegediend wordt aan de bodem, 2) bemesting met een lage C-input waarbij alleen mineralenconcentraat toegediend wordt aan de bodem en 3 ) bemesting met standaard C-input, waarbij zowel runder-, vleesvarkens- en zeugendrijfmest toegediend wordt (Tabel 4). Op het perceel met biologische bemesting zijn vanaf 2000 metingen gedaan, maar voor de andere twee percelen zijn alleen data van 2011 t/m 2016 beschikbaar met één gewasrotatie voor alle drie de bemestingstypen. De gewasrotatie bestaat uit aardappelen, conservenerwt, prei, zomergerst, suikerbiet en snijmais $(n=6)$. Op het perceel met biologische input wordt peen gekweekt in plaats van suikerbiet. De gemeten veranderingen in OSgehalte zijn variabel en de periode van 2011 t/m 2016 is te kort om inzicht te krijgen in de verandering in koolstofvoorraad. Daarom is besloten om deze metingen nog drie keer te herhalen $\mathrm{t} / \mathrm{m}$ 2034. Om de weerdata voor de koolstofmodellen te extrapoleren, worden de KNMI-data van 2002 gebruikt. Dit jaar wordt gezien als representatief jaar zonder grote extremen. De gewasresten van zomergerst en prei worden afgevoerd. De gewasresten en/of stoppels van de andere gewassen worden in de bodem ondergewerkt.

Tabel 4 Organische mestgiften (ton vers) voor drie verschillende behandelingen voor de proeflocatie in Vredepeel.

\begin{tabular}{llrrr} 
Jaar & Gewas & Biologische & Laag & \\
2011 & Aardappel & 47 & 0 & 30 \\
\hline 2012 & Doperwt & 10 & 0 & 20 \\
\hline 2013 & Prei & 28 & 0 & 0 \\
\hline 2014 & Zomergerst & 20 & 0 & 30 \\
\hline 2015 & Suikerbiet/peen & 40 & 0 & 35 \\
\hline 2016 & Snijmais & 60 & 35 \\
\hline
\end{tabular}

\subsection{Beschrijving aanpak}

Om de modellen op een consistente manier met elkaar te vergelijken, is het belangrijk dat de inputdata zo veel mogelijk hetzelfde zijn. Op deze manier zijn verschillen in de resultaten meest waarschijnlijk te verklaren door de werking en parametrisatie van het model. Voor de vergelijkbaarheid zijn de volgende aannames gemaakt:

- De startwaarde van het organischestofgehalte in de bodem is het eerste jaar waarin metingen plaatsvonden. Voor MAK is hiervoor het OS-gehalte van 2007 genomen die bepaald is door middel van 'loss on ignition' en voor Vredepeel is het OS-gehalte van 2011 genomen die bepaald is met de Near InfraRed (NIR) methode.

- De bodemmonsters zijn genomen op $25 \mathrm{~cm}$ diepte, maar de modellen gaan ervan uit dat het OSgehalte dat op deze diepte gemeten is, representatief is voor de bovenste dertig centimeter.

- Voor omrekening van OS-percentage naar totaal C-gehalte is aangenomen dat de bodem-organische stof voor de helft uit C bestaat. Dit geldt voor zowel zand- als kleibodems (Pribyl et al., 2010).

- Voor Vredepeel ontbraken gegevens van de gewasresten (bovengrondse stoppel) van snijmais in 2016. Hiervoor is een waarde van 1 ton $\mathrm{C} / \mathrm{ha}$ aangenomen.

- $\mathrm{Er}$ is voor MAK en Vredepeel gerekend met verschillende weerdata: voor MAK zijn data uit KNMI zone 5 gebruikt en voor Vredepeel uit KNMI zone 14.

- Voor Vredepeel was maar een periode van zes jaar aan data beschikbaar. Aangezien dit voor bodem C-modellering een korte periode is, is deze rotatie nog drie keer herhaald en daarmee is een periode van 2011-2034 doorgerekend.

- Voor de toekomstige jaren (2018-2034) is gerekend met de weerdata van 2002. Dit is een standaardjaar in het NDICEA-model. 
- De klei- en silt-percentages van de bodem zijn in het geval van Vredepeel in het laboratorium gemeten. Bij de MAK-data zijn kleigehalte en de afslibbaarheid gemeten en het silt-percentage is geschat met de door Eurofins gehanteerde formule Afslibbaar $\%=\mathrm{klei} \%+0.3 *$ silt $\%$.

- De modellen werken met vooraf gedefinieerde gewassen en meststoffen om C-input af te leiden. In het geval dat een gewas of meststof niet beschikbaar is in het model, dan is deze vervangen door een alternatief met vergelijkbare eigenschappen.

- Indien drogestof- en C-gehaltes van meststoffen, gewassen of gewasresten niet expliciet zijn opgegeven, zijn de standaardwaarden van het model genomen. Voor Vinassekali wordt een C-gehalte van 29,9\% aangehouden (Harry Verstegen, pers.com).

De modellen leveren voor de vergelijking als resultaat de berekende totale jaarlijkse koolstofinput naar de bodem en de koolstofvoorraad voor de bovenste bodemlaag $(0-30 \mathrm{~cm})$. De verschillen tussen de modellen en de verschillen tussen gemeten en gesimuleerde OS-gehaltes zullen worden geëvalueerd. Deze evaluatie zal meegenomen worden in de discussie omtrent de geschiktheid van de modellen voor het ontwikkelen van een praktijkmodel voor bodem C-berekeningen.

In sommige gevallen is het gewas of de meststof niet beschikbaar in het model en moet deze vervangen worden door een alternatief met vergelijkbare eigenschappen. Voor CCB worden schorseneer en pastinaak vervangen door peen, omdat peen een vergelijkbare humificatie-coëfficiënt (d.w.z. coëfficiënt voor het omzetten van vers organisch materiaal in stabielere organische stof) en hoeveelheid gewasresten heeft na oogst. In RothC worden deze gewassen vervangen door 'overige groenten'. Schorseneer en pastinaak zijn wel beschikbaar voor NDICEA. Hetzelfde geldt voor pompoen en prei. Voor CCB en RothC zijn deze gewassen vervangen door aardappel, omdat bij deze gewassen een geringe hoeveelheid organische stof achterblijft, met een relatief lage humificatie-coëfficiënt. In $\mathrm{CCB}$ is suikermais vervangen door corncobmix en conservenerwt door voedererwt. In RothC worden deze gewassen vervangen door respectievelijk mais en peulvruchten.

Voor Vredepeel wordt voor bemestingstype 'laag' en 'standaard' de groenbemester Engels raai geoogst waarbij de gewasresten worden afgevoerd. In CCB en NDICEA is deze teelt opgenomen als hoofdgewas, omdat afvoer van gewasresten bij invoer van groenbemester niet mogelijk is. Groenbemesters waarvan de oogst niet wordt afgevoerd (zoals grasklaver en Japanse haver), zijn in NCIDEA en CCB opgenomen als rogge. In RothC wordt geen onderscheid gemaakt tussen verschillende typen groenbemester.

Voor de drie bemestingstypen in Vredepeel zijn ook de hoeveelheden bovengrondse stoppel gemeten. In RothC en NDICEA zijn deze data gebruikt als input. NDICEA berekent de ondergrondse stoppel afhankelijk van het gewas - met behulp van omrekeningsfactoren. RothC doet dit niet. Voor CCB is het niet mogelijk om gemeten hoeveelheden stoppel in te voeren. Het betreft namelijk een vaste waarde, afhankelijk van het gewas.

Voor CCB worden de inputdata gecorrigeerd indien drogestof- (ds) en C-gehaltes van meststoffen zijn gemeten. Bijvoorbeeld, rundveedrijfmest heeft binnen CCB een standaard ds-gehalte van $10 \%$ en een C-gehalte van 30\% van de ds. De rundveedrijfmest toegepast op Vredepeel-bio heeft een C-gehalte vers van 3,2\%. Als in het bio-scenario 1 ton rundveedrijfmest toegediend wordt, wordt dat binnen CCB vertaald naar 1,0667 ton om aan dezelfde C-invoer te komen. Voor de drie MAK-scenario's met dierlijke mest of $\mathrm{gft}$ is dezelfde werkwijze toegepast.

Vinassekali, toegepast in het Vredepeel-bio-scenario, is voor de modellen ingevoerd als zuiveringsslib, met een correctie voor het opgegeven C-gehalte van 29,9\% (Harry Verstegen, pers.com.). Het C-gehalte van vaste rundermest en rundveedrijfmest in de Vredepeel-scenario's zijn overgenomen door alle drie de modellen zoals opgegeven op basis van algemene cijfers van De Haan et al. (2017). Voor MAK zijn deze data wel gemeten. We zien dat ondanks de gedetailleerde data die beschikbaar zijn voor deze twee proeflocaties, het lastig blijft om de modelinput consistent en compleet te krijgen. Pragmatische keuzes zijn daardoor soms noodzakelijk. 


\subsection{Resultaten}

\subsubsection{Koolstofaanvoer}

Door de verschillende aannames zitten er kleine verschillen in de totale jaarlijkse koolstofinput tussen de drie modellen. De koolstofinput bestaat uit groenbemester, externe OS-input en gewasresten. Voor RothC, dat als voorbeeld in Figuur 1 is weergegeven, fluctueert de koolstofinput op de locatie MAK tussen de 0,8 en 8,4 ton $\mathrm{C} /$ ha. De koolstofinput tussen de verschillende percelen ligt in sommige jaren dichter bij elkaar dan in andere. Met name de totale koolstofinput met potstalmest ligt in 7 van de 12 jaren (een stuk) hoger dan in de andere scenario's. Voor de locatie Vredepeel geldt ook dat de totale koolstofinput tussen de drie modellen kleine verschillen vertoont vanwege de aannames. De koolstofinput van RothC fluctueert in Vredepeel tussen de 0,6 en 5,7 ton C/ha. Het biologische perceel ontvangt een afwijkende hoeveelheid organische input. In de jaren dat de organische stof aanvoer voor de scenario's 'laag' en 'standaard' laag is, is deze voor het scenario 'biologisch' juist hoog (Figuur 2).

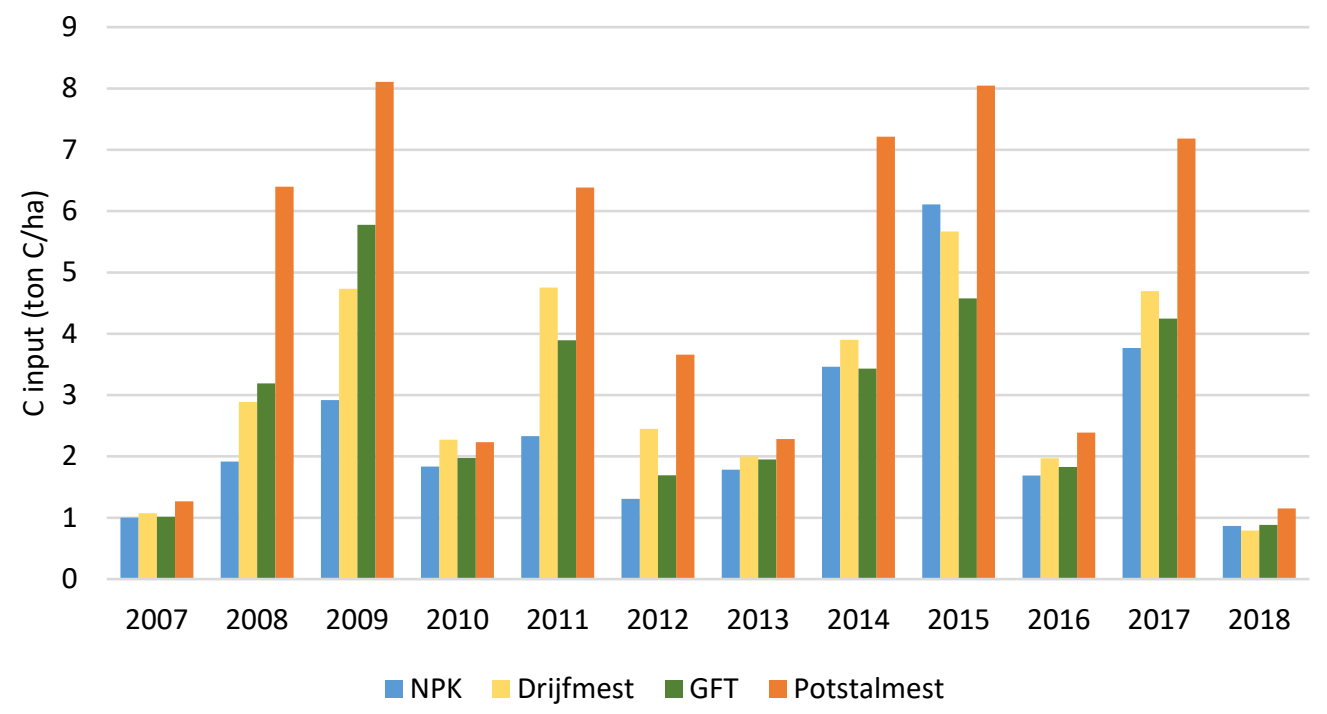

Figuur 1 Totale koolstof input voor de vier behandelingen in 'Mest als Kans' (Lelystad).

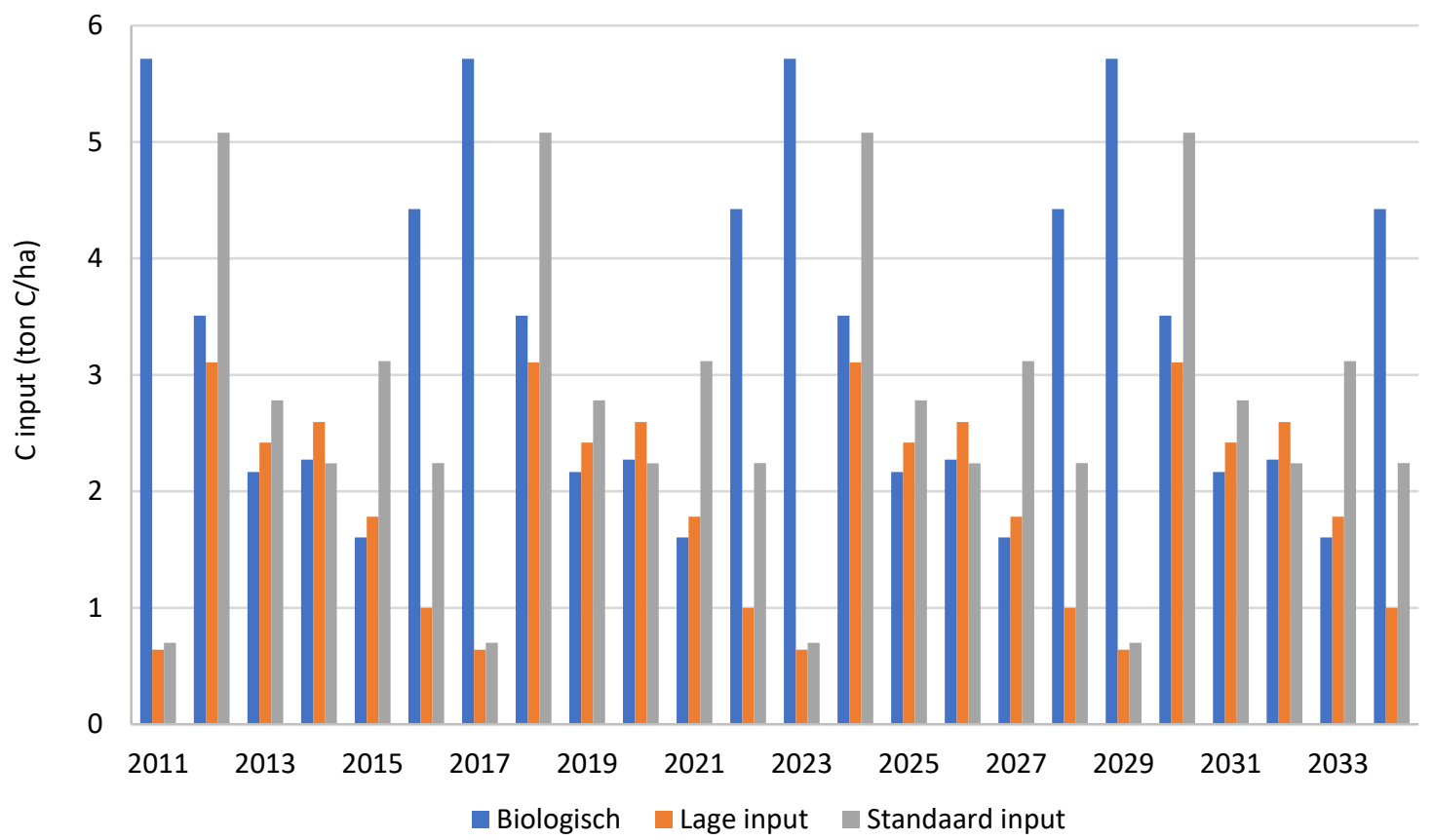

Figuur 2 Totale koolstofinput voor de drie behandelingen in Vredepeel. 


\subsubsection{Koolstofvoorraad}

In MAK zien we dat alle drie de modellen een stijgende koolstofvoorraad simuleren voor het perceel waar potstalmest wordt toegediend en RothC en NDICEA een lichte daling simuleren voor het perceel waar alleen NPK wordt toegediend (Figuur 3). De koolstofvoorraad blijft min of meer gelijk in de percelen waar rundveedrijfmest of gft-compost wordt toegediend. De resultaten van CCB geven een veel hogere koolstofvoorraad vergeleken met RothC en NDICEA, die dichtbij elkaar liggen. De gemeten OS-gehaltes zijn weergegeven in Figuur 5. Echter, een trend op basis van twee metingen is gezien de onzekerheid in de bodem OS-bepaling eigenlijk niet goed mogelijk.
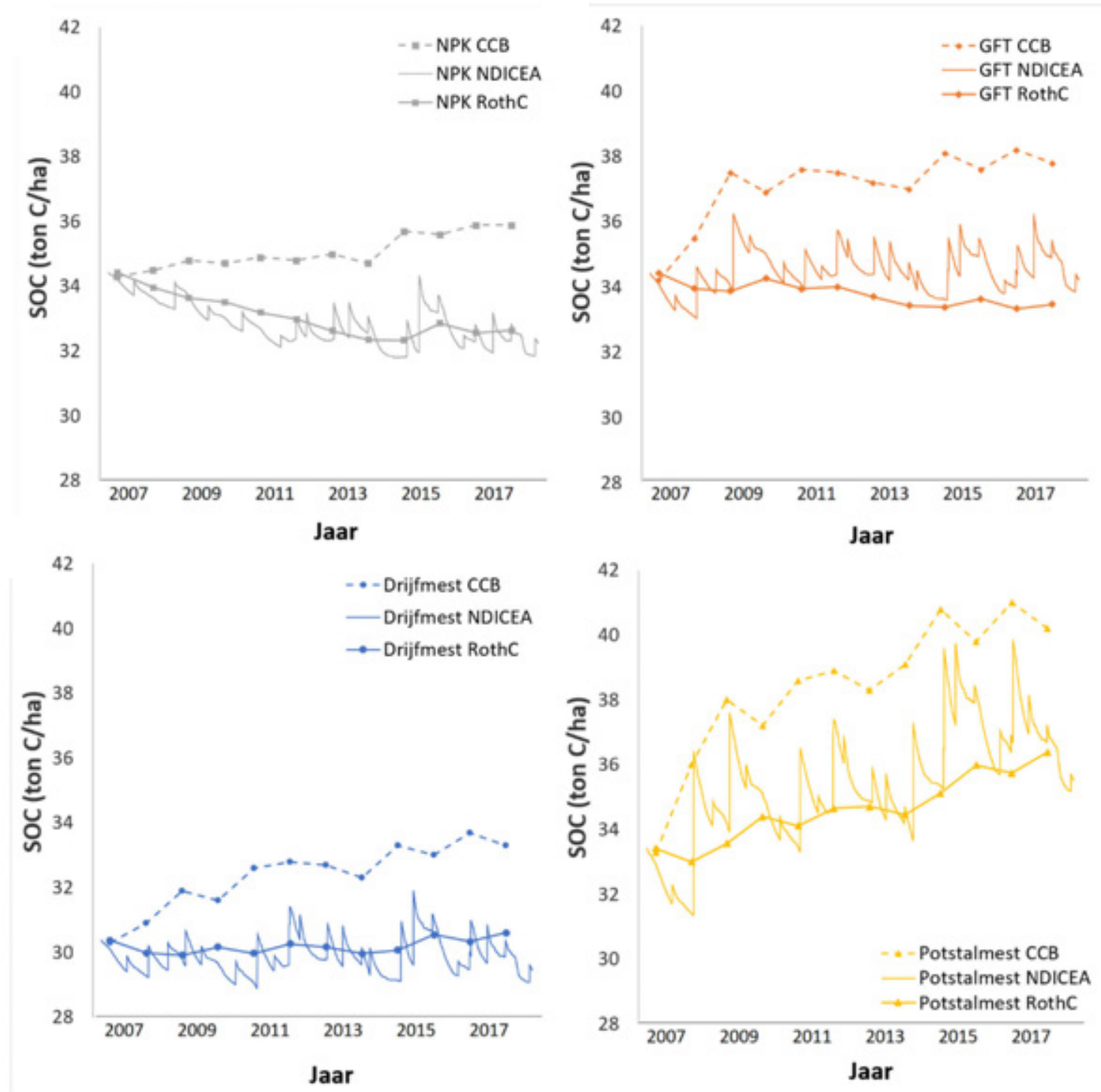

Figuur 3 Voor vier verschillende behandelingen en drie verschillende modellen zijn bodemorganische stof (SOC) gehaltes gesimuleerd (locatie: 'Mest als Kans' in Lelystad).

Voor de Vredepeel-percelen zien we dat de koolstofvoorraad volgens alle drie de modellen en voor alle drie de behandelingen afneemt. Echter de snelheid waarmee de koolstofvoorraad afneemt, verschilt per model. NDICEA laat de kleinste daling zien en RothC de grootste. In de eerste zes jaar van de simulatie zijn de resultaten van RothC en CCB vrijwel gelijk, terwijl daarna voor de langere termijn RothC een sterkere daling voorspelt in vergelijking met de resultaten van CCB. NDICEA en RothC laten vergelijkbare resultaten zien voor de behandeling 'laag'. Alleen voor de mesttoediening 'laag' en 'standaard' zijn langetermijnexperimenten beschikbaar. De gemeten OS-gehaltes zijn weergegeven in Figuur 6 en deze wijzen uit dat de afname in OS-gehalte die RothC laat zien, minder realistisch is dan die van $\mathrm{CCB}$. 

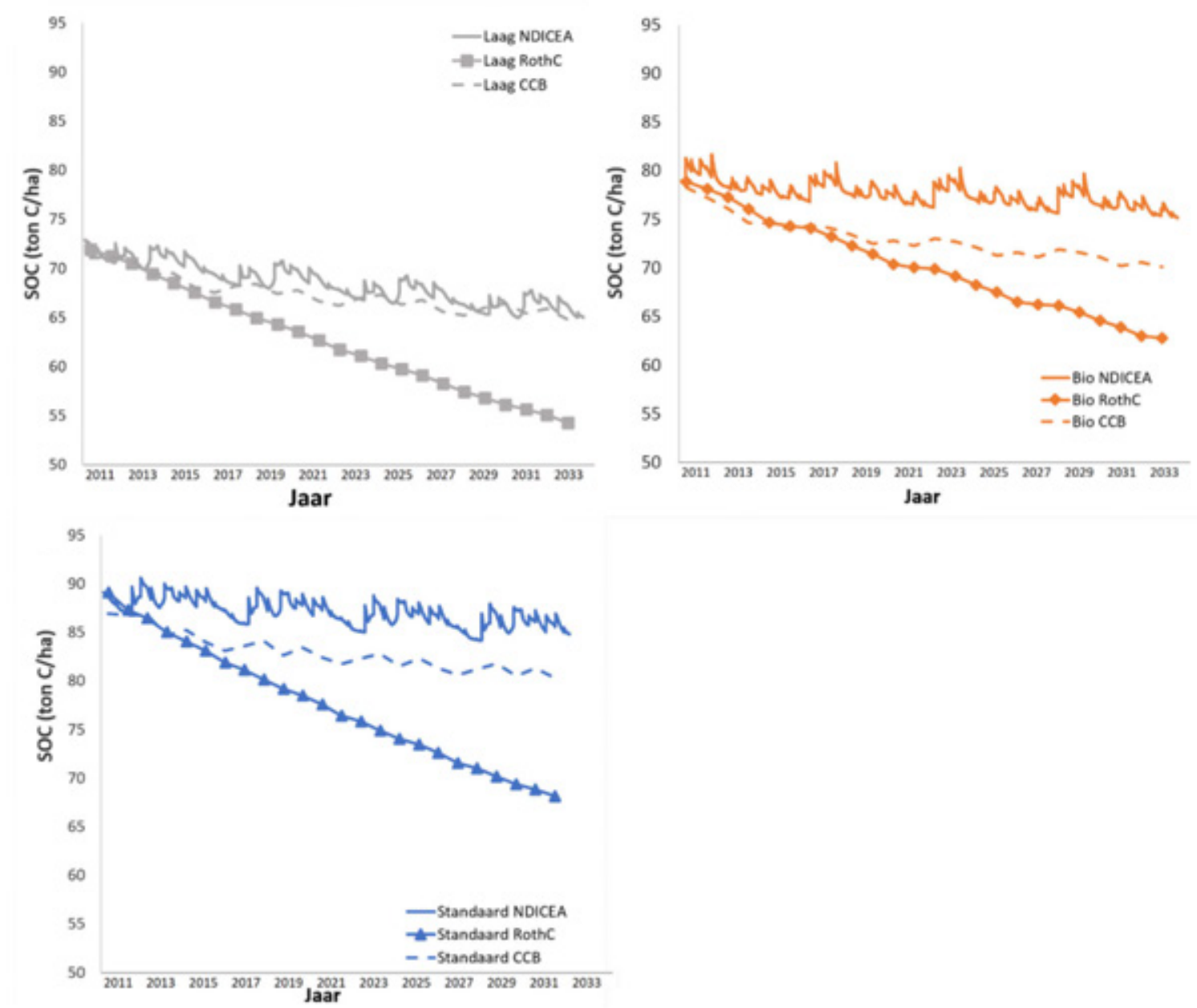

Figuur $4 \quad$ Voor drie verschillende behandelingen en drie verschillende modellen zijn bodemorganische stof (SOC) gehaltes gesimuleerd (locatie: Vredepeel).

\subsection{Discussie}

Uit de vergelijking wordt duidelijk dat er behoorlijke verschillen zijn tussen de modellen, waardoor de verandering in bodem $\mathrm{C}$ op basis van simulatie behoorlijk onzeker is. Voor MAK voorspellen de modellen NDICEA en RothC dezelfde trend en wijkt CCB hiervan af. Voor Vredepeel voorspellen alle drie de modellen dezelfde trend, maar laat RothC een veel sterkere daling in koolstofvoorraad zien dan NDICEA en voor de langere termijn ook vergeleken met CCB. Voor een volgende fase is het belangrijk om een modelvergelijking uit te voeren waarbij specifiek gekeken wordt naar bodemmaatregelen, aangezien het dan belangrijk is dat modellen elkaar niet gaan tegenspreken. De absolute toe- of afname in bodem $\mathrm{C}$ is dan minder van belang, maar de richting van verandering moet wel consistent voorspeld worden. Voor de proeflocatie MAK simuleert CCB een hogere C-vastlegging dan NDICEA en RothC. We zien bij CCB vooral in de eerste jaren een sterke toename in koolstofvoorraad, terwijl deze in de jaren daarna stabiliseert. De initialisatie van het model zou dan ook een mogelijke verklaring kunnen zijn voor de hogere koolstofvastlegging bij CCB voor MAK. De hogere koolstofvastlegging zoals berekend met CCB voor de MAK-proef kan ook verklaard worden door het bodemtype in Flevoland. CCB is erg gevoelig voor het kleigehalte van de betreffende bodem. Mogelijk wordt de remmende invloed van het kleigehalte op de afbraak van organische stof overschat.

Voor de Vredepeel-resultaten kunnen de verschillen deels verklaard worden door een specifieke aanpassing in de afbraak voor NDICEA. NDICEA heeft een correctiefactor voor zandgronden zonder leem. Zodra het OS-gehalte hoger is dan $2 \%$, wordt er aangenomen dat er $2 \%$ actieve OS aanwezig is. Het resterende percentage wordt toegevoegd aan een langzamere OS-/C-pool. Deze aanpassing is gemaakt om bodems met oude koolstof, zoals enkeerd- en moerige gronden, beter te kunnen 
simuleren. Aangezien Vredepeel gelegen is op een veenontginning, is het vrij goed mogelijk dat er in de bodem nog oude stukken veen vermengd zijn en dat deze bodem dus een hoger OS-gehalte heeft dan je normaal gesproken bij een zandgrond verwacht. Door deze aanpassing simuleert NDICEA in dit geval waarschijnlijk beter dan RothC en CCB.

De modellen zijn ontwikkeld en gekalibreerd onder verschillende situaties. Dit kan ook de verschillen tussen de modellen verklaren. RothC is bijvoorbeeld gekalibreerd met data uit Rothamsted (dominant klei), CCB is vooral gekalibreerd op Midden-Europese bodems, waar kleibodems relatief ondervertegenwoordigd zijn. Toepassing van CCB op kleigrond zou nog een extra validatiestap vereisen. NDICEA is vooral getest en gekalibreerd voor stikstofdynamiek en niet specifiek op koolstof. Hoewel de kalibratiedata in Nederland zijn genomen, heeft de parametrisatie van de koolstofafbraak plaatsgevonden onder gecontroleerde condities (dus niet in een veldsituatie).

Op basis van deze twee datasets is moeilijk te zeggen welk model het best de organische-stofvoorraad simuleert, aangezien er slechts beperkte meetdata zijn (Figuur 5 en Figuur 6). Voor Vredepeel is er wel bijna jaarlijks gemeten, maar voor de percelen die in deze studie meegenomen zijn, zijn er data beschikbaar voor slechts zes jaar (Figuur 6). Hieruit is nog geen duidelijke trend van toe- of afname waar te nemen. Zes jaar is te kort om duidelijke verschillen is OS-gehalte te krijgen. Voor de proeflocatie MAK zijn er voor drie jaar data beschikbaar (2007, 2012 en 2016). Echter, de bodemanalyses voor de tweede meting (2012) zijn uitgevoerd in een ander laboratorium dan de eerste en derde meting en wijken nogal af, waardoor ze niet bruikbaar zijn. De onzekerheid in de bodem OS-bepaling maakt het niet mogelijk om te spreken van een trend gebaseerd op twee meetmomenten. Op basis van de eerste (2007) en laatste meting (2016) is wel duidelijk dat voor het perceel met potstalmest de grootste toename is gemeten (van 1,65\% naar 2,1\% OS). Voor potstalmest lijkt CCB dus de beste schatting te maken, omdat de stijging van RothC en NDICEA gering is. Voor drijfmest en gft is de toename in OS-gehalte volgens CCB ongeveer $0,2 \%$. Voor de andere twee modellen en voor NPK is het OS-gehalte min of meer gelijk gebleven.

De gemeten en gesimuleerde OS-gehaltes voor MAK en Vredepeel zijn weergegeven in respectievelijk Figuur 5 en Figuur 6. Voor MAK volgt CCB de gemeten OS-gehaltes het best, alhoewel de gemeten OS-gehalte voor de behandeling NPK hoger uitvalt dan gesimuleerde waardes. Voor de locatie Vredepeel simuleren CCB en RothC vergelijkbare OS-gehaltes. In de gemeten OS-gehaltes zit ook een grote spreiding. Zo zijn voor 2015 in alle drie de behandelingen hogere OS-gehaltes gemeten dan gesimuleerd. 


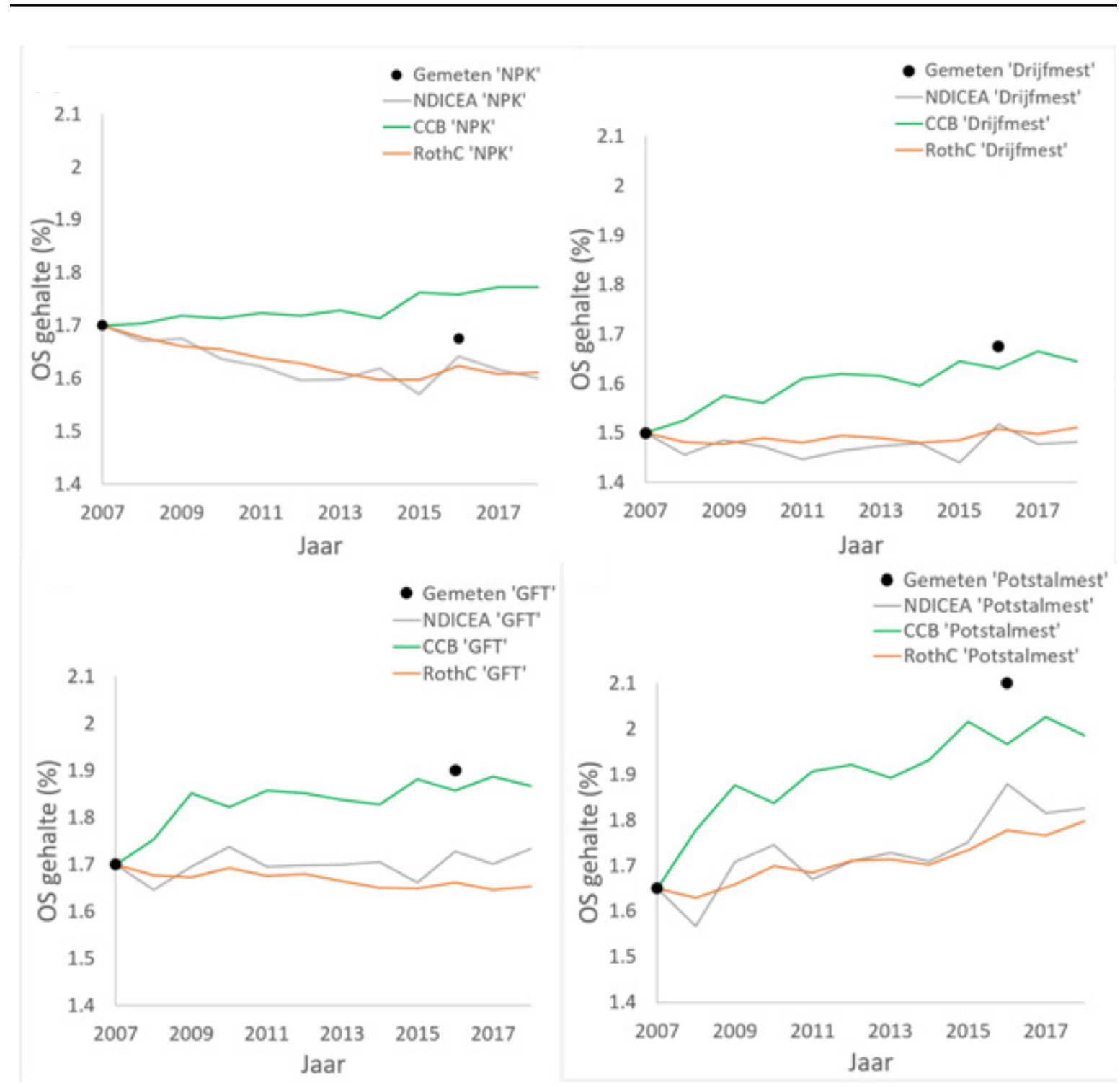

Figuur 5 De gemeten (zwarte punten) en gesimuleerde (gekleurde lijnen) OS-gehaltes voor vier behandelingen en drie verschillende koolstofmodellen (locatie: 'Mest als Kans' in Lelystad). 


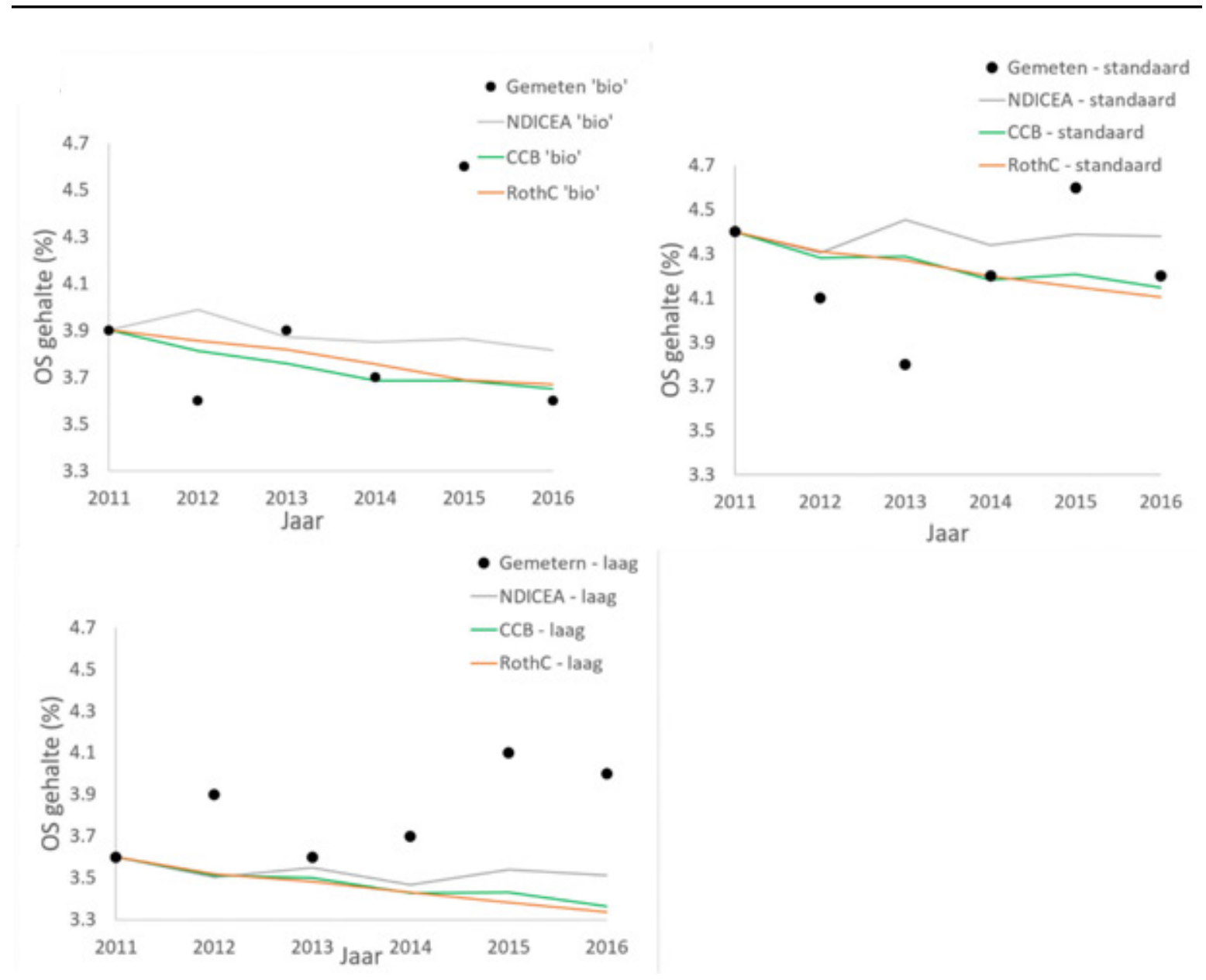

Figuur 6 De gemeten (zwarte punten) en gesimuleerde (gekleurde lijnen) OS-gehaltes voor drie behandelingen en drie verschillende koolstofmodellen (locatie: Vredepeel). 


\section{Simuleren van maatregelen}

Het rapport van Lesschen et al. (2012) presenteert een tabel met bodem C-maatregelen en de potentiële koolstofvastlegging die deze maatregelen kunnen bewerkstelligen. Aan de hand van een literatuurstudie is deze tabel vernieuwd. De maatregelen kunnen onderverdeeld worden in drie categorieën: grondbewerking, externe aanvoer OS en interne OS-input. Tabel 5 toont de bodem $\mathrm{C}$-maatregelen en de geschiktheid per model om deze maatregelen te simuleren. Met de geschiktheid bedoelen we de mogelijkheid van het model om een maatregel te simuleren. Dit zegt nog niets over de kwaliteit van de resultaten. De geschiktheid van de modellen wordt hierna per categorie in meer detail beschreven.

Tabel 5 Bodem C-maatregelen en de geschiktheid van de geselecteerde koolstofmodellen om deze maatregel te simuleren (groen = geschikt, oranje = nu nog niet geschikt, maar met aanpassingen evt. wel geschikt te maken, rood = niet geschikt).

\begin{tabular}{|c|c|c|c|c|}
\hline & \multirow[t]{2}{*}{ Maatregel } & \multicolumn{3}{|c|}{ Geschiktheid model voor simulatie van maatrege } \\
\hline & & CCB & NDICEA & RothC \\
\hline \multirow[t]{3}{*}{ Grondbewerking } & Niet-kerende grondbewerking & & & \\
\hline & Geen grondbewerking & & & \\
\hline & Niet scheuren grasland & & & \\
\hline \multirow[t]{2}{*}{ Externe aanvoer OS } & Dierlijke mest toevoegen & & & \\
\hline & Compost toevoegen & & & \\
\hline \multirow[t]{5}{*}{ Interne input OS } & Gewasresten achterlaten & & & \\
\hline & Verbeteren gewasrotaties & & & \\
\hline & Kruidenrijk grasland & & & \\
\hline & Agroforestry & & & \\
\hline & Vanggewas/groenbemester & & & \\
\hline
\end{tabular}

\subsection{Grondbewerking}

Maatregelen als niet-kerende grondbewerking, geen grondbewerking en niet scheuren grasland kan koolstofvastlegging bevorderen. Bij niet-kerende grondbewerking wordt de bodem niet of alleen oppervlakkig bewerkt. In de literatuur worden tegensprekende effecten van niet-kerende grondbewerking op koolstofvastlegging beschreven. Deze tegenspraak lijkt vooral veroorzaakt door verschillen in de bodemdiepte waarover de analyse plaatsvindt. Andere factoren die meespelen, zijn klimaat, management en bodemtype (Luo et al., 2010). In het algemeen wordt er een toename van koolstofvastlegging in de bovenste bodemlaag geconstateerd en een afname van koolstofvastlegging in diepere bodemlagen $(>25 \mathrm{~cm}$ ). Het is van belang dat deze maatregel doorgerekend kan worden op perceelniveau, zodat individuele bedrijven zelf het effect van deze maatregel op boven- en ondergrond kunnen doorrekenen (ervan uitgaande dat benodigde gegevens beschikbaar zijn).

\subsubsection{NDICEA}

De totale bodemorganische stof in NDICEA is verdeeld over een aantal fracties. Iedere fractie wordt gekarakteriseerd door een specifieke afbraakconstante, afhankelijk van de relatieve leeftijd van een fractie. De afbraak wordt per dag (tijdstap in het model) gecorrigeerd door vermenigvuldiging met vier correctiefactoren (temperatuur, bodemvocht, zuurgraad en een 'decayfactor', zie hieronder). Deze factoren beïnvloeden (verlagen resp. verhogen) direct de hoeveelheid afgebroken organisch materiaal en ook de snelheid waarmee de relatieve leeftijd van organisch materiaal toeneemt. Als de afbraak van organisch materiaal geremd wordt, verandert de kwaliteit (en dus de relatieve leeftijd) ook minder (Janssen, 1984). 
De decayfactor is afhankelijk van grondsoort én grondbewerking. Verschillen in grondbewerking zijn afgeleid uit Koopmans et al. (2014). Deze verschillen kunnen in het model doorgevoerd worden door de waarden van de decayfactor te veranderen. In de literatuur komen verschillen voor ten aanzien van het effect van grondbewerkingsintensiviteit. De auteurs van dit rapport hebben daarom een gemiddelde verwachting genomen over 15 tot 100 jaar om op middellange- en lange termijn de effecten van grondbewerkingsintensiteit te simuleren. Koopmans et al. (2014) concludeerden uit een simulatie van een aantal praktijkscenario's met de afgeleide waarden van de decayfactor dat kalibratie nodig was. Dit was vooral het geval bij behandelingen met ondiepere grondbewerking. De grote variatie binnen de maatregel 'ondieper ploegen' maakt het moeilijk te interpreteren (bijv. hoe diep, hoe vaak, welke machines etc.). Dit leverde veel variatie in resultaten, zoals de literatuurreview van Koopmans et al. (2014) ook liet zien. Na kalibratie van het model, waarbij OS-gehaltes tweemaal gemeten werden in verschillende behandelingen, gaf de simulatie wel een bevredigend resultaat volgens Koopmans et al. (2014).

In de praktijk zullen de grondsoort en de grondbewerkingsintensiteit worden gekozen door de gebruiker. Een zandgrond met conventionele grondbewerking is gekozen als standaard met een decayfactor van 1. Tabel 6 toont de decayfactor voor verschillende bodemsoorten en grondbewerkingsintensiteiten die in het model gekozen kunnen worden. Desgewenst kan deze ook handmatig aangepast worden om andere situaties door te rekenen.

Tabel 6 De waarde van de decayfactor in NDICEA als functie van grondsoort (lichtere grondsoorten: snellere afbraak) en bodembewerking (intensievere bodembewerking: snellere afbraak).

\begin{tabular}{lrrr} 
Bodemsoort & $\begin{array}{c}\text { Conventionele } \\
\text { grondbewerking }\end{array}$ & $\begin{array}{c}\text { Gereduceerde } \\
\text { grondbewerking }\end{array}$ \\
Leemarm zand & 1 & 0,85 & 0,71 \\
\hline Veen & 1 & 0,85 & 0,71 \\
\hline Grof zand & 1 & 0,85 & 0,71 \\
\hline Zwak lemig zand & 1 & 0,85 & 0,71 \\
\hline Sterk lemig zand & 0,96 & 0,78 \\
\hline Loss & 0,92 & 0,75 \\
\hline Zeer licht zavel (11-16\% slib) & 0,89 & 0,73 \\
\hline Matig lichte zavel (17-24\% slib) & 0,86 & 0,65 \\
\hline Lichte klei (36-49\% slib) & 0,78 & 0,66 \\
\hline Matig zware klei (50-71\% slib) & 0,71 & 0,60 \\
\hline
\end{tabular}

Langjarig grasland en het scheuren van grasland kunnen ook gemodelleerd worden met NDICEA. NDICEA berekent de toename van organische stof tijdens de graslandfase, maar dit wordt pas toegevoegd aan de bodem op het moment van scheuren. Dus zolang er niet gescheurd wordt, zit deze 'organische stof' niet in het bodemcompartiment, maar in de plant (= zode). NDICEA hanteert hierbij een vaste fractie organische stof-afbraak door het scheuren van grasland. Daarnaast komt door scheuren een hoeveelheid vers organisch materiaal in de bodem met aanvankelijk een relatief hoge afbraaksnelheid (zoals dat ook voor ander vers plantenmateriaal geldt). Deze afwijking van wat er in de praktijk kan gebeuren (bijv. driejarig grasland met jaarlijkse extra OS naar de bodem), komt doordat NDICEA ontwikkeld is als model voor de akkerbouw, waar meestal eenjarig grasland als afwisseling van akkerbouwteelten werd toegepast.

\subsubsection{CCB}

CCB hanteert vier OS-/C-pools van organische stof die variëren van zeer labiel tot zeer stabiel. Ieder van deze pools volgt een eerste ordeafbraak, die afhangt van klimaat, bodemtype en ploegregime (van conventioneel ploegen tot niet-kerende grondbewerking). De bijdrage van achtergebleven gewasresten aan bodemorganische stof is gewas-specifiek en hangt af van de hoeveelheid gewasresten, de stabiliteit daarvan en de humificatie-coëfficiënt. Deze eigenschappen kunnen worden gemodelleerd voor verschillende delen van de plant, waardoor er rekening gehouden kan worden met het eventueel onderwerken van gewasreten. CCB rekent ook stikstofdynamiek uit, maar dit heeft geen 
gevolgen voor het koolstofverlies. Kruidenrijk grasland en het (niet) scheuren van grasland kan beperkt worden meegenomen via de effecten op C-input. Het is niet mogelijk om biologische interacties tussen soorten te simuleren.

\subsubsection{RothC}

RothC is een model met vier OS-/C-pools die verschillen in relatieve afbraakconstanten. Het standaardmodel kan alternatieven in grondbewerking momenteel niet simuleren, aangezien het werkt met één bodemlaag en omdat het wel of niet ploegen geen effect heeft op de afbraakcoëfficiënt. Dit laatste wordt in veel andere modellen met één factor gesimuleerd (zie NDICEA waarbij een correctie op de afbraakfactor wordt toegepast) of met de IPCC-methodiek opgelost waarbij de bodem C-voorraad met een bepaalde factor wordt verhoogd als er niet-kerende of geen grondbewerking wordt toegepast. Zo'n factor zou aan RothC kunnen worden toegevoegd of worden afgeleid op basis van literatuur.

Scheuren van grasland kan al wel door het model gesimuleerd worden, aangezien de factor voor bodembedekking dan verandert en ook de C-aanvoer naar de bodem kan voor de duur van het scheuren worden aangepast. In het TKI project 'Belang van vastlegging van koolstof in de bodem voor mitigatie van broeikasgassen' voor de melkveehouderij zijn voor het scheuren van grasland al testen gedaan met RothC. Hieruit bleek dat RothC in staat is scheuren te simuleren door C-input en grondbedekking in het model te wijzigen. Echter, een goede termijnproef waarin dit is getest en die als validatie gebruikt kan worden, is er niet.

\subsection{Externe aanvoer organische stof}

\subsubsection{NDICEA}

In de huidige versie van NDICEA zijn 47 verschillende typen van externe organische stof-aanvoer gedefinieerd. Voor alle typen zijn er standaardwaarden in het model aanwezig wat betreft toedieningshoeveelheid, tijdstip, relatieve leeftijd van de OS, fractie droge stof en fractie $\mathrm{C}$, en N, P en $\mathrm{K}$. Deze kunnen gemakkelijk gewijzigd worden om eigen input te creëren.

\subsubsection{CCB}

De bijdragen van externe organische stof aan de bodem OS-/C-pool wordt uitgerekend aan de hand van het C-gehalte, de stabiliteit en de humificatie-coëfficiënt van het toegevoerde materiaal. Met deze eigenschappen wordt uitgerekend hoe groot de bijdrage van de aangevoerde organische stof aan de verschillende pools is. Deze zijn voor een groot aantal OS-bronnen al gedefinieerd en kunnen naar behoefte worden toegevoegd.

\subsubsection{RothC}

In RothC kan externe aanvoer van organische stof in de vorm van mest of compost direct als inputdata ingevoerd worden. De verschillen tussen de mestsoorten komen met de huidige parametrisatie met name tot uitdrukking door verschillen in aanvoer, aangezien bijv. vaste mest meer $\mathrm{C}$ bevat dan drijfmest. Het model zou echter ook kunnen rekenen met specifieke verdelingen over de verschillende C-pools per mestsoort. Er lopen nu meerdere experimenten binnen WUR waarbij in respiratieproeven de humificatie-coëfficiënten van verschillende (nieuwe) mestsoorten worden bepaald. Deze zouden in de toekomst gebruikt kunnen worden om het model te verbeteren. 


\subsection{Interne input organische stof}

\subsubsection{NDICEA}

NDICEA rekent met verschillen in gewasrotaties en in groenbemesters en bevat invoerdata van 140 verschillende gewassen en 28 verschillende groenbemesters. In het model zijn de gewassen opbrengst-gestuurd, waarbij de gebruiker de opbrengst van het hoofdproduct opgeeft met een zaaien oogsttijdstip. Het model berekent de opbrengst van bovengrondse en ondergrondse delen, de opname van $\mathrm{N}, \mathrm{P}$ en $\mathrm{K}$ en de gewasresten in de verschillende bodemlagen. In NDICEA kunnen standaardwaarden voor C-aanvoer (afkomstig uit praktijkonderzoek in Nederland) voor de verschillende gewassen en groenbemesters gebruikt worden. Verder zijn alle eigenschappen van de gewassen aan te passen. Een limitatie van het model is dat rotaties tot twaalf jaar gedefinieerd kunnen worden. Door een aantal cycli achter elkaar door te rekenen, zou je meer dan twaalf jaar kunnen simuleren.

NDICEA maakt onderscheid in inputgegevens voor gras en grasklaver. Het simuleren van kruidenrijk grasland is mogelijk na aanpassing van de bestaande parameters voor gras of grasklaver. De volgende parameters zouden dan aangepast moeten worden: opbrengstniveau, bewortelingsdiepte, de verhouding bovengrondse en ondergrondse organische stof en de verdeling van organische stof over de bodemlagen. Het opbrengstniveau en de bewortelingsdiepte zijn direct door de gebruiker aan te passen. Dit geldt niet voor de verhouding van bovengrondse en ondergrondse organische stof, waarvoor een gebruiker meerdere aanpassingen moet doen. De huidige versie van NDICEA verdeelt gewasresten en organische stof nog niet over verschillende bodemlagen ( $100 \%$ toediening aan de bouwvoor).

\subsubsection{CCB}

CCB berekent de input en output van koolstof met een tijdstap van een jaar. Invoer van de exacte datum van gebeurtenissen zoals oogsten, ploegen of bemesten is wel mogelijk, maar dit dient alleen ter documentatie en speelt geen rol in de berekening. De input van organische stof uit verbouwde gewassen (hoofdgewas en groenbemester) en bemesting wordt in het jaar van oogsten toegevoegd aan de bodem OS-/C-pool. Bij meerdere oogsten in één jaar, zoals bij het verbouwen van een zomergewas na groenbemester of winterprei, wordt de totale aanvoer van organisch materiaal dus berekend uit de som van beide oogsten. De bijdrage van verbouwde gewassen aan de bodemkoolstof wordt bepaald aan de hand van de hoeveelheid achtergebleven materiaal en de kwaliteit daarvan. De hoeveelheid achtergebleven materiaal hangt af van de geoogste hoeveelheid en de fractie hiervan die achterblijft. Om de achterblijvende fractie te berekenen, wordt elk gewas onderverdeeld in een deel dat altijd wordt afgevoerd (doeloogst), een mogelijk onder te werken deel (gewasresten) en een deel dat bij de oogst niet kan worden verwijderd (achterblijvende resten). De relatieve bijdrage van achterblijvende delen naar bodem $\mathrm{C}$ hangt af van gewas-specifieke afbraaksnelheid en humificatiecoëfficiënt.

Voor kruidenrijk grasland zouden in CCB specifieke verdelingen van boven- en ondergronds materiaal kunnen worden gedefinieerd, maar het is niet mogelijk om veranderingen in bewortelingsdiepte mee te nemen, omdat in CCB koolstof homogeen aan de bouwvoor wordt toebedeeld. Veranderingen in de soortenverdeling van kruidenrijk grasland zal handmatig moeten worden ingevoerd, omdat plantengroei niet expliciet wordt gemodelleerd.

\subsubsection{RothC}

In RothC wordt geen onderscheid gemaakt tussen bovengrondse en ondergrondse gewasresten, zoals in NDICEA en CCB, omdat RothC maar één omrekeningsfactor gebruikt die de totale resten berekent als functie van gewasopbrengst. RothC gebruikt parameters voor het berekenen van de hoeveelheid groenbemester of vanggewas die in de bodem gewerkt wordt.

RothC rekent met gewasrotaties, maar de standaardinterface kan hierin slechts één gewas per jaar doorrekenen. Zodra er meer dan één gewas tegelijkertijd op een perceel staat, zal de gebruiker het 
perceel moeten opsplitsen en later de resultaten van de opgesplitste percelen bij elkaar moeten optellen. Een nadeel hiervan is dat het model geen rekening houdt met de interactie die het gewas ondervindt van het andere gewas in het geval van kruidenrijk grasland of agroforestry. Als echter op basis van literatuur en experimentele data afgeleid kan worden hoeveel de aanvoer van $\mathrm{C}$ naar de bodem toeneemt voor maatregelen als kruidenrijk grasland of agroforestry, dan kan dat wel worden meegenomen in het model. Effecten van vastlegging in diepere bodemlagen kunnen niet worden gesimuleerd, omdat evenals bij NDICEA slechts één bodemlaag gesimuleerd wordt waarvoor meestal de bouwvoor gekozen wordt. $\mathrm{Er}$ is al een experimentele versie van RothC in de literatuur beschreven waarin meerdere bodemlagen kunnen worden gesimuleerd (Dechow et al., 2019), maar het is nog niet duidelijk of deze versie geschikt is voor de Nederlandse situatie. 


\section{$7 \quad$ Conclusies en aanbevelingen}

- Gedurende de loop van dit project is duidelijk geworden dat er op dit moment nog niet voor één model gekozen moet worden als praktijkmodel. Elk model heeft voor- en nadelen en is meer of minder geschikt voor het doorrekenen van bepaalde bodem C-maatregelen.

- De drie modellen die uiteindelijk in de kwantitatieve analyse zijn meegenomen, verschillen wel duidelijk van elkaar. In termen van complexiteit en benodigde inputdata is NDICEA het veeleisendst, aangezien het model op dagbasis rekent, interactie heeft met stikstof en gewasgroei simuleert. NDICEA kan echter ook met minder input worden toegepast, maar dat is in de simulaties nog niet getest. RothC is het minst complex en heeft daardoor ook minder inputdata nodig en CCB zit qua complexiteit en inputdata tussen NDICEA en RothC in. CCB heeft een bepaald gebruikersgemak als voordeel; ook door mensen met weinig kennis van het model kunnen maatregelen om bodem $C$ te verhogen worden ingevoerd.

- De keuze welk model te gebruiken als praktijkmodel hangt sterk af van de doelen waarvoor het gebruikt gaat worden. Wanneer het model alleen voor monitoring van bodem $\mathrm{C}$ geschikt moet zijn, dan zou RothC een logische keuze zijn, aangezien het inputdata vraagt die makkelijk te verkrijgen zijn, de broncode makkelijk aan te passen is en grote datasets (veel percelen) goed zou kunnen doorrekenen voor de lange termijn. Als het doel gericht is op advisering van boeren, zou NDICEA geschikter zijn, omdat het uitgebreide output geeft en ook interacties met stikstof- (en fosfaat)bemesting meeneemt.

- De modellen zijn ontwikkeld en gekalibreerd onder verschillende situaties. Daardoor zal de kwaliteit van de resultaten ook ruimtelijke en temporele variatie vertonen. Welk model het geschiktst is onder welke Nederlandse omstandigheden kan niet met overtuiging geconcludeerd worden uit deze studie. Een multi-model ensemble is een interessant alternatief om de trend in SOC stock met meer zekerheid te voorspellen. Riggers et al. (2019) concluderen dat een multi-modelanalyse de onzekerheid in gesimuleerde SOC stocks reduceert.

- Om een goed beeld te krijgen van de veranderingen in koolstofvoorraad onder huidig en alternatief landgebruik zijn langetermijndata nodig. Het doorrekenen van meer langetermijn-experimenten en bedrijfsrotaties uit de Slim Landgebruik-netwerken met de modellen, biedt naast kwantitatieve resultaten voor de desbetreffende proef/rotatie ook beter inzicht op het functioneren van verschillende modellen. In Nederland zijn maar zeer beperkte langetermijn- datasets voor bodem $\mathrm{C}$ beschikbaar. In andere landen, waaronder Duitsland, Denemarken, Oostenrijk en Engeland liggen meer langetermijnexperimenten. Deze zouden gebruikt kunnen worden om de drie modellen beter te valideren en ook om het effect van verschillende maatregelen verder door te rekenen. Langetermijndata kunnen ook gebruikt worden voor validatie van de modellen en voor een gevoeligheidsanalyse.

- Voor een consistentere kwantitatieve modelvergelijking zou als alternatief voor een langetermijnexperiment, ook een fictief proefveld met klassieke akkerbouwrotatie (tarwe, bieten, aardappelen) gebruikt kunnen worden. Bestaande praktijkdata hebben vaak geen consistente meetreeks ter beschikking en de twee proeflocaties hanteren geen klassieke akkerbouwrotatie.

- Een volgende stap is om de potentiële praktijkmodellen te testen op bedrijven binnen de pilots van het Slim Landgebruik-programma. Hieruit zal blijken in hoeverre de benodigde inputdata daadwerkelijk beschikbaar zijn en of deze makkelijk uit de bedrijfsmanagementsystemen te halen zijn. Daarnaast zouden dan ook de effecten van voorgestelde bodem C-maatregelen doorgerekend kunnen worden voor de desbetreffende bedrijven. Met medewerking van de sector zou het praktijkmodel binnen één à twee jaar operationeel en toepasbaar kunnen zijn. 


\section{Literatuur}

Buendia, E.C., Guendehou, S., Limmeechokchai, B., Pipatti, R., Rojas, Y., Sturgiss, R., Tanabe, K., Wirth, T., Romano, D., Witi, J., Grag, A., Weitz, M.M., Cai, B., Ottinger, D.A., Dong, H., MacDonald, J.D., Ogle, S.M., Rocha, M.T., Sanchez, M.J., Bartram, D.M., Towprayoon, S. (2019): 2019 Refinement to the 2006 IPCC Guidelines for National Greenhouse Gas Inventories. IPCC, Technical Support Unit c/o Institute for Global Environmental Strategies. Kanagawa, Japan.

Coleman, K., Jenkinson, D.S. (1996): RothC-26.3 - A model for the turnover of carbon in soil. In: Powlson, D.S., Smith, P., Smith, J.U. (Eds.), Evaluation of Soil Organic Matter Models Using Existing Long-Term Datasets. Springer-Verlag, Heidelberg, pp. 237-246.

De Haan, J.J., M. Wesselink, W. van Dijk, H.A.G. Verstegen, W.C.A. van Geel, W. van den Berg (2017): Effect van organische stofbeheer op opbrengst, bodemkwaliteit en stikstofverliezen op een zuidelijke zandgrond. Resultaten van de gangbare bedrijfssystemen van het project Bodemkwaliteit op zand in de periode 2011-2016. Wageningen Research, Rapport WPR-754. 108 blz.; 31 fig.; 45 tab.; 51 ref.

Dechow, R., Franko, U., Kätterer, T., Kolbe, H. (2019): Evaluation of the RothC model as a prognostic tool for the prediction of SOC trends in response to management practices on arable land. Geoderma 337: 463-478. doi: 10.1016/j.geoderma.2018.10.001.

Franko, U., Kolbe, H., Thiel, E., Ließ, E. (2011): Multi-site validation of a soil organic matter model for arable fields based on generally available input data. Geoderma 166, pp. 119-134. doi: 10.1016/j.geoderma.2011.07.019.

Franko, U., Oelschlägel. B., Schenk, S. (1995): Simulation of Temperature-, Water- and Nitrogen dynamics using the Model CANDY. Ecological Modelling, 81, pp. 213-222. doi: 10.1016/03043800(94)00172-E.

Hillier, J., Walter, C., Malin, D., Garcia-Suarez, T., Mila-i-Canals, L., \& Smith, P. (2011): A farmfocused calculator for emissions from crop and livestock production. Environmental Modelling \& Software, 26(9), pp. 1070-1078.

Izaurralde, R. C., Williams, J. R., McGill, W. B., Rosenberg, N. J., Quiroga Jakas, M. C. (2006): Simulating soil $\mathrm{C}$ dynamics with EPIC: Model description and testing against long-term data. Ecological Modelling 192(3-4), pp. 362-384. doi: 10.1016/j.ecolmodel.2005.07.010.

Janssen B.H. (1984): A simple method for calculating decomposition and accumulation of 'young' soil organic matter. Plant and Soil 76: 297-304.

Koopmans, C.J., Rietberg, P., van der Burgt, G.J. (2014): Calibration and adaptation of the NDICEA model to reduced tillage systems. Final report for the CORE Organic II funded project. Work package 5.2. Publication number: 2014-019 LbP. 48 p.

Krinner, G., Viovy, N., de Noblet-Ducoudré, N., Ogée, J., Polcher, J., Friedlingstein, P., Ciais, P., Sitch, S.; Prentice, I. C. (2005): A dynamic global vegetation model for studies of the coupled atmosphere-biosphere system. Global Biogeochemical Cycles, 19 (1).

Lesschen, J.P., Heesmans, H., Mol-Dijkstra, J., van Doorn, A., Verkaik, E., van den Wyngaert, I., Kuikman, P. (2012): Mogelijkheden voor koolstofvastlegging in de Nederlandse landbouw en natuur. Wageningen, Alterra, Alterra-rapport 2396. 62 blz.; 7 fig.; 19 tab.; 57 ref. 
Li, C., Frolking, S., Harriss, R. (1994): Modeling carbon biogeochemistry in agricultural soils. Global Biogeochemical Cycles, 8, pp. 237-254. doi: 10.1029/94GB00767.

Luo, Z., Wang, E., Sun, O.J. (2010): Can no-tillage stimulate carbon sequestration in agricultural soils? A meta-analysis of paired experiments. Agriculture Ecosystems \& Environment 139: 224-231. DOI: 10.1016/j.agee.2010.08.006. doi: 10.1016/j.agee.2010.08.006.

NMI (2014): Organische stof rekentool. https://www.nmi-agro.nl/tools/organische-stof-rekentool. Geraadpleegd op 20 juni 2019.

Parton, W. J., Hartman, M., Ojima, D., Schimel, D. (1998): DAYCENT and its land surface submodel: description and testing. Global and planetary Change, 19, pp. 35-48. doi: 10.1016/S09218181(98)00040-X.

Parton, W.J., Ojima, D., Schimel, D., Kittel, T.G.F. (1992): Development of simplified ecosystem models for applications in Earth system studies: the CENTURY experience. Earth system modelling, pp. 281-302.

Parton, W.J., Rasmussen, P.E. (1994): Long-term effects of crop management in wheat-fallow: II. CENTURY model simulations. Soil Sci. Soc. Am. J. 58, 530-536. doi: 10.2136/sssaj1994.03615995005800020040x

Pribyl, D. W. (2010): A critical review of the conventional SOC to SOM conversion factor. Geoderma, 156, 75-83. doi:10.1016/j.geoderma.2010.02.003.

Rietberg, P., Van der Burgt, G-J. (2012): Mest Als Kans 2012: Activiteiten en resultaten. Bedrijfsoptimale bemesting. Louis Bolk Institute BO-12.03-002-023.

Riggers, C., Poeplau, C., Don, A., Bamminger, C., Hoper, H., Dechow, R. (2019): Multi-model ensemble improved the prediction of trends in soil organic carbon stocks in German croplands. Geoderma 345, 17-30. doi: 10.1016/j.geoderma.2019.03.014.

Smit, A.B., Breemer, A.M., Rietberg, P., Reijs, J.W., Venema, G.S. (2019): Ontsluiting van en koppeling aan praktijkdata over bodemgebruik en bodemmanagement; Doordacht landgebruik project 1.7: Ontsluiting data voor projecten 1.2 en 3.1. Wageningen, Wageningen Economic Research. Concept rapport.

Van der Burgt, G.J.H.M., Oomen, G.J.M., Habets, A.S.J., Rossing, W.A.H. (2006): The NDICEA model, a tool to improve nitrogen use efficiency in cropping systems. Nutrient Cycling in Agroecosystems 74: 275. Doi: 10.1007/s10705-006-9004-3.

Zwart, K., Kikkert, A., Wolfs, A., Termorshuizen, A., Van der Burgt, G. (2013): De organische stof balans met de te verwachten stikstoflevering per teeltrotatie: Opzet en gebruikswijze van een rekenmodule. Masterplan Mineralenmanagement, proj.nr. 12059. doi: 10.1007/s10705-006-9004-3. 


\section{Bijlage 1 Gedetailleerde beschrijving bodem C-modellen}

\begin{tabular}{|c|c|}
\hline Model naam & CANDY \\
\hline Versie & 3.20 .17 .36 \\
\hline Datum laatste versie & 19.04 .2018 \\
\hline Ontwikkelaar & Helmholz Centre for Environmntal Research - UFZ \\
\hline Website & http://www.ufz.de/index.php?en=39725 \\
\hline Handleiding (link) & http://www.ufz.de/export/data/2/95948_CANDY_MANUAL.pdf \\
\hline Wetenschappelijk gepubliceerd & Ja \\
\hline \multirow[t]{3}{*}{ Referenties - modelbeschrijving } & $\begin{array}{l}\text { Franko, U., Oelschlägel. B., Schenk, S. (1995): Simulation of Temperature, Water } \\
\text { and Nitrogen dynamics using the Model CANDY. Ecol. Model., 81, S. 213-222 }\end{array}$ \\
\hline & $\begin{array}{l}\text { Franko, U., Crocker, G.J., Grace, P.R., Klir, J., Körschens, M., Poulton, P.R., } \\
\text { Richter, D.D. (1997): Simulating trends in soil organic carbon in long-term } \\
\text { experiments using the CANDY model. Geoderma, } 81,109-120\end{array}$ \\
\hline & $\begin{array}{l}\text { Franko, U., Mirschel, W. (2001): Integration of a Crop Growth Model with a Model of } \\
\text { Soil Dynamics. Agronomy Journal, 93, S. } 60-66\end{array}$ \\
\hline Validatie & $\begin{array}{l}\text { Franko, U., Kuka, K., Romanenko, I. A., Romanenkov, V. A. (2007): Validation of the } \\
\text { CANDY model with Russian long-term experiments. Regional Environmental Change } 7 \\
\text { (2), 79-91 }\end{array}$ \\
\hline Toepassing & $\begin{array}{l}\text { Franko, U., RÜHLMANN, J., (1991): Simulation of C-dynamics and N-dynamics in } \\
\text { sandy soil used for vegetable production. Gartenbauwissenschaft; } 56: 174-179 .\end{array}$ \\
\hline Review & $\begin{array}{l}\text { Smith, P., Smith, J.U., Powlson, D.S., McGill, W.B., Arah, J.R.M., Chertov, O.G., } \\
\text { Coleman, K., Franko, U. et al. (1997): A comparison of the performance of nine soil } \\
\text { organic matter models using datasets from seven long-term experiments. Geoderma, } \\
81, \text { S. } 153-225\end{array}$ \\
\hline Publiek beschikbaar & Ja \\
\hline Licentie voor commercieel gebruik & Niet bekend \\
\hline Code/rekenregels openbaar? & Nee \\
\hline $\begin{array}{l}\text { Temporele resolutie (reken } \\
\text { tijdstap) }\end{array}$ & Dag \\
\hline $\begin{array}{l}\text { Temporele extent (duur van } \\
\text { simulatie) }\end{array}$ & Decennia \\
\hline Ruimtelijke resolutie & Microschaal - plotschaal \\
\hline Bodemdiepte/bodemlagen & 1D-model in blokken van $10 \mathrm{~cm}$. Binnen elke laag is er een verdeling van poriën. \\
\hline $\begin{array}{l}\text { Toepassingsgebied (qua klimaat, } \\
\text { bodems, landgebruik) }\end{array}$ & akkerbouw en grasland in gematigde zones \\
\hline $\begin{array}{l}\text { Stikstofinteracties? (incl. } \mathrm{N}_{2} \mathrm{O}- \\
\text { emissies) }\end{array}$ & Eigen stikstofmodel, inclusief $\mathrm{N}_{2} \mathrm{O}$-productie \\
\hline Relatie met waterbalans? & Eigen watermodule \\
\hline $\begin{array}{l}\text { Welke processen worden er } \\
\text { gemodelleerd? }\end{array}$ & Opname en groei plant, afbraak SOM, stikstofdynamiek \\
\hline $\begin{array}{l}\text { Welke maatregelen kunnen } \\
\text { doorgerekend worden? }\end{array}$ & Grondbewerking, opbrengen organisch materiaal, bemesting \\
\hline Benodigde inputparameters & $\begin{array}{l}\text { Verdeling OS/C pools, Klimaat, N-input, C-input, eigenschappen plant (bouwplan, } \\
\text { planteigenschappen), wateropbrengst, bodemstructuur (porieverdeling) }\end{array}$ \\
\hline \multicolumn{2}{|l|}{ Outputparameters } \\
\hline Export format & SQL-database \\
\hline Beschrijving OS-/C-pools & Vers organisch materiaal, labiel SOM, stabiel SOM, inert SOM \\
\hline SOM-dynamiek & $\begin{array}{l}\text { Eerste orde afbraak met limitatie door beperkte uur van activiteit bij suboptimale } \\
\text { omstandigheden (biological active time/BAT) }\end{array}$ \\
\hline $\begin{array}{l}\text { OS-/C-pools meetbaar of } \\
\text { conceptueel }\end{array}$ & Beiden is mogelijk \\
\hline Type interface & Local GUI \\
\hline OS & Windows \\
\hline
\end{tabular}




\begin{tabular}{ll} 
Model naam & CANDY \\
\hline API beschikbaar of te maken? & Nee, en sourcecode is niet beschikbaar \\
\hline Gevalideerd? Waarvoor? & Beperkt \\
\hline Bestaande (praktijk)toepassingen & In gebruik bij HelmHolzinstituut \\
\hline Bestaande implementaties (link) & http://www.ufz.de/index.php?en=39725 \\
\hline Zwakke punten & Code niet openbaar, geen API, weinig toepassingen en validatie \\
\hline Sterke punten & Meetbare OS-/C-pools \\
\hline Overige opmerkingen & Contact: Prof. Dr. Hans-Jörg Vogel \\
& Department of Soil System Science \\
& hans-joerg.vogel@ufz.de
\end{tabular}

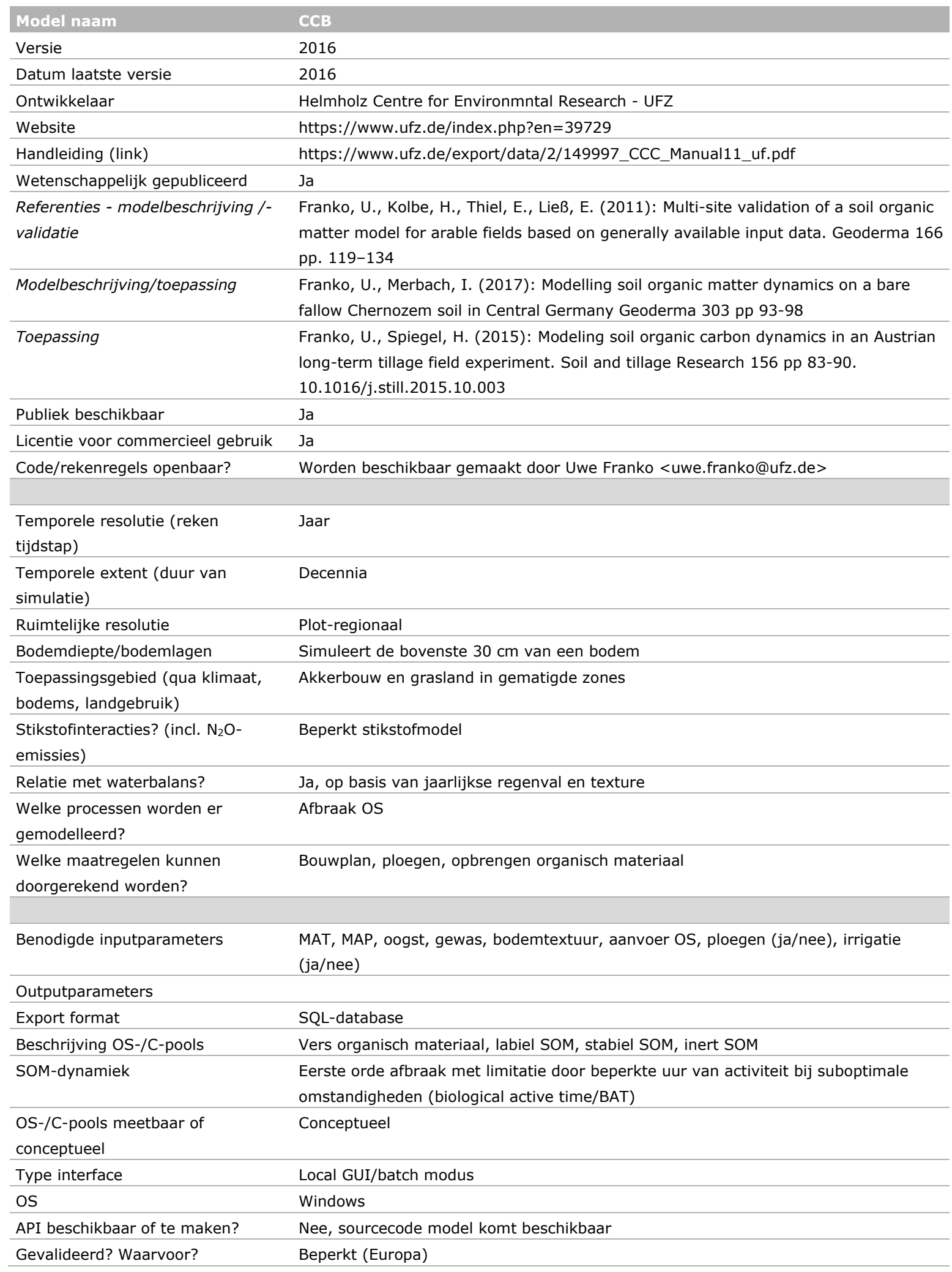




\begin{tabular}{ll} 
Model naam & CCB \\
Bestaande (praktijk)toepassingen & In gebruik bij HelmHolzinstituut \\
\hline Bestaande implementaties (link) & https://www.ufz.de/index.php?en=39729 \\
\hline Zwakke punten & Beperkt toegepast en gevalideerd \\
\hline Sterke punten & Uwe Franko <uwe.franko@ufz.de> \\
\hline Overige opmerkingen & Contact: Prof. Dr. Hans-Jörg Vogel \\
& Department of Soil System Science \\
& hans-joerg.vogel@ufz.de / Uwe Franko <uwe.franko@ufz.de>
\end{tabular}

\begin{tabular}{|c|c|}
\hline Model naam & Century \\
\hline Versie & Century 4.6 \\
\hline \multicolumn{2}{|l|}{ Datum laatste versie } \\
\hline Website & http://www.nrel.colostate.edu/projects/century \\
\hline Handleiding (link) & $\begin{array}{l}\text { https://www2.nrel.colostate.edu/projects/century/MANUAL/html_manual/man96.htm } \\
\text { I\#CULT100 }\end{array}$ \\
\hline Wetenschappelijk gepubliceerd & ja \\
\hline Referenties - modelbeschrijving & $\begin{array}{l}\text { Parton, W.J., D.S. Ojima, D.S. Schimel, and T.G.F. Kittel. 1992. Development of } \\
\text { simplified ecosystem models for applications in Earth system studies: the CENTURY } \\
\text { experience. Pages } 281-302 \text { in D.S. Ojima, editor. Earth system modeling. } \\
\text { Proceedings from the } 1990 \text { Global Change Institute on Earth System Modeling, } \\
\text { Snowmass, Colorado, USA. ( } 689\end{array}$ \\
\hline Toepassing & $\begin{array}{l}\text { Kelly, R.H., W.J. Parton, G.J. Crocker, P.R. Grace, J. Klir, M. Korschens, P.R. Poulton, } \\
\text { and D.D. Richter. 1997. Simulating trends in soil organic carbon in long-term } \\
\text { experiments using the CENTURY model. Geoderma } 81: 75-90 .\end{array}$ \\
\hline Review & $\begin{array}{l}\text { Byrne, Kenneth \& Kiely, Ger. (2009). Evaluation of Models (PaSim, RothC, CENTURY } \\
\text { and DNDC) for Simulation of Grassland Carbon Cycling at Plot, Field and Regional } \\
\text { Scale. }\end{array}$ \\
\hline Publiek beschikbaar & $\mathrm{Ja}$ \\
\hline Ruimtelijke resolutie & Plot- en landschapsniveau \\
\hline Bodemdiepte/bodemlagen & Top 20 cm (dieper kan maar dan moeten parameters worden aangepast) \\
\hline $\begin{array}{l}\text { Toepassingsgebied (qua klimaat, } \\
\text { bodems, landgebruik) }\end{array}$ & $\begin{array}{l}\text { Grasland, akkerbouw, bos en savannes op verschillende gronden, in verschillende } \\
\text { klimaatzones }\end{array}$ \\
\hline $\begin{array}{l}\text { Stikstofinteracties? (incl. } \mathrm{N}_{2} \mathrm{O}- \\
\text { emissies) }\end{array}$ & Eigen stikstofmodel \\
\hline Relatie met waterbalans? & Eigen watermodel \\
\hline $\begin{array}{l}\text { Welke processen worden er } \\
\text { gemodelleerd? }\end{array}$ & Stikstofbalans, koolstofbalans, fosforbalans, zwavelbalans \\
\hline $\begin{array}{l}\text { Welke maatregelen kunnen } \\
\text { doorgerekend worden? }\end{array}$ & Grondbewerking, bouwplan, organische stof input \\
\hline Benodigde inputparameters & $\begin{array}{l}\text { Maandelijkse minimum- en maximumtemperatuur, maandelijkse neerslag, } \\
\text { bodemtextuur, N-, P- en S-gehalte van de plant, lignine gehalte van het } \\
\text { plantmateriaal, atmosferische en bodem N-input, en de initiële bodem C- en } \\
\text { N-gehaltes (P en S zijn optioneel) }\end{array}$ \\
\hline Outputparameters & Fluxen van $\mathrm{C}, \mathrm{N}, \mathrm{P}$, en $\mathrm{S}$ \\
\hline
\end{tabular}




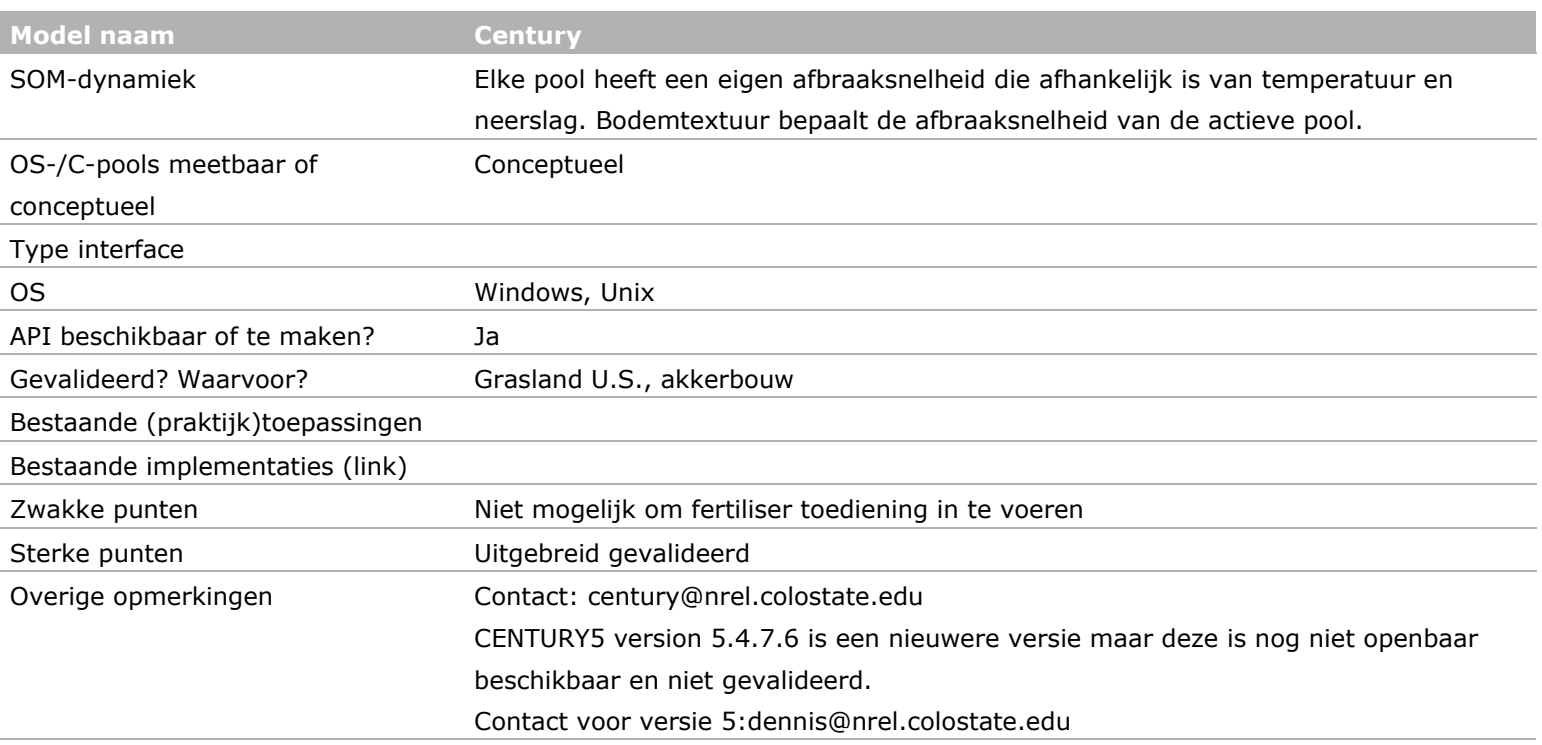

\begin{tabular}{|c|c|}
\hline Model naam & Cool Farm Tool \\
\hline Versie & The Cool Farm Tool Version 2.0 - beta 3 \\
\hline \multicolumn{2}{|l|}{ Datum laatste versie } \\
\hline Website & https://coolfarmtool.org/ \\
\hline Handleiding (link) & https://coolfarmtool.org/wp-content/uploads/2016/09/Data-Input-Guide.pdf \\
\hline Wetenschappelijk gepubliceerd & $\mathrm{Ja}$ \\
\hline Referenties - modelbeschrijving & $\begin{array}{l}\text { Hillier, J., Walter, C., Malin, D., Garcia-Suarez, T., Mila-i-Canals, L., \& Smith, P. } \\
\text { (2011). A farm-focused calculator for emissions from crop and livestock } \\
\text { production. Environmental Modelling \& Software, 26(9), 1070-1078. }\end{array}$ \\
\hline Review & $\begin{array}{l}\text { Hillier, J., Abdalla, M., Bellarby, J., Albanito, F., Datta, A., Dondini, M., ... \& } \\
\text { Kuhnert, M. (2016). Mathematical modeling of greenhouse gas emissions from } \\
\text { agriculture for different end users. Synthesis and Modeling of Greenhouse Gas } \\
\text { Emissions and Carbon Storage in Agricultural and Forest Systems to Guide Mitigation } \\
\text { and Adaptation, (advagricsystmodel6), 197-228. }\end{array}$ \\
\hline Publiek beschikbaar & $\mathrm{Ja}$ \\
\hline Licentie voor commercieel gebruik & Nee \\
\hline Code/rekenregels openbaar? & $\mathrm{Ja}$ \\
\hline $\begin{array}{l}\text { Toepassingsgebied (qua klimaat, } \\
\text { bodems, landgebruik) }\end{array}$ & Wereldwijd \\
\hline $\begin{array}{l}\text { Stikstofinteracties? (incl. } \mathrm{N}_{2} \mathrm{O}- \\
\text { emissies) }\end{array}$ & $\begin{array}{l}\text { Cool Farm Tool berekent } \mathrm{N}_{2} \mathrm{O} \text {-emissies van bemesting etc., maar directe link met } \\
\text { bodem } \mathrm{C} \text { is er niet }\end{array}$ \\
\hline Relatie met waterbalans? & Nee \\
\hline $\begin{array}{l}\text { Welke processen worden er } \\
\text { gemodelleerd? }\end{array}$ & $\begin{array}{l}\text { Geen processen, wel wordt effect van groenbemester, grondbewerking redelijk } \\
\text { meegenomen }\end{array}$ \\
\hline $\begin{array}{l}\text { Welke maatregelen kunnen } \\
\text { doorgerekend worden? }\end{array}$ & Verandering in grondbewerking, bouwplan, organische stof input \\
\hline
\end{tabular}


Model naam

Benodigde inputparameters

Algemene info perceel, opbrengst, bodemtextuur, SOM, bodemvocht, $\mathrm{pH}$, gewasresten aan- of afvoer, bemesting, verandering in landgebruik of grondbewerking, groenbemesters, energiegebruik en transport (optioneel)

\section{Outputparameters} Totale emissies bedrijf

Export format

Beschrijving OS-/C-pools

SOM-dynamiek

Een pool, totale OS-voorraad

Geen

OS-/C-pools meetbaar of

Meetbaar, totaal OS

conceptueel

Type interface Website

Operating System OS-onafhankelijk

API beschikbaar of te maken? Ja

Gevalideerd? Waarvoor? Nee

Bestaande (praktijk)toepassingen

Bestaande implementaties (link)

Zwakke punten

Ja, wordt al op grote schaal (duizenden bedrijven) toegepast

www.coolfarmtool.org

Gebaseerd op IPCC stock change methodiek, daardoor ongeschikt voor monitoren van bodem C, o.a. door gebruik van discrete bodem C-klassen i.p.v. continue data

Sterke punten Al sterke toepassing in praktijk, koppeling aan andere datasystemen

Overige opmerkingen

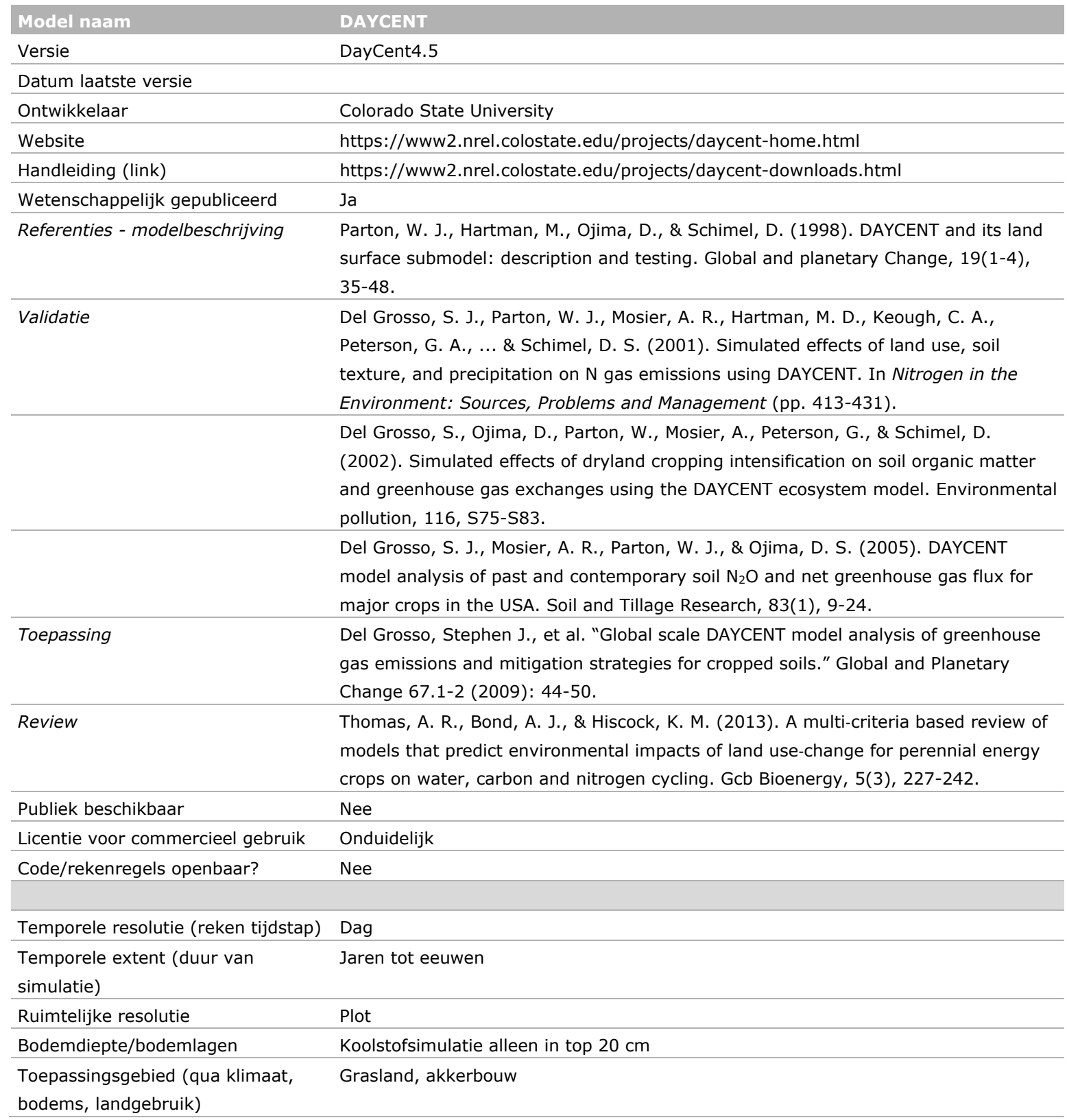






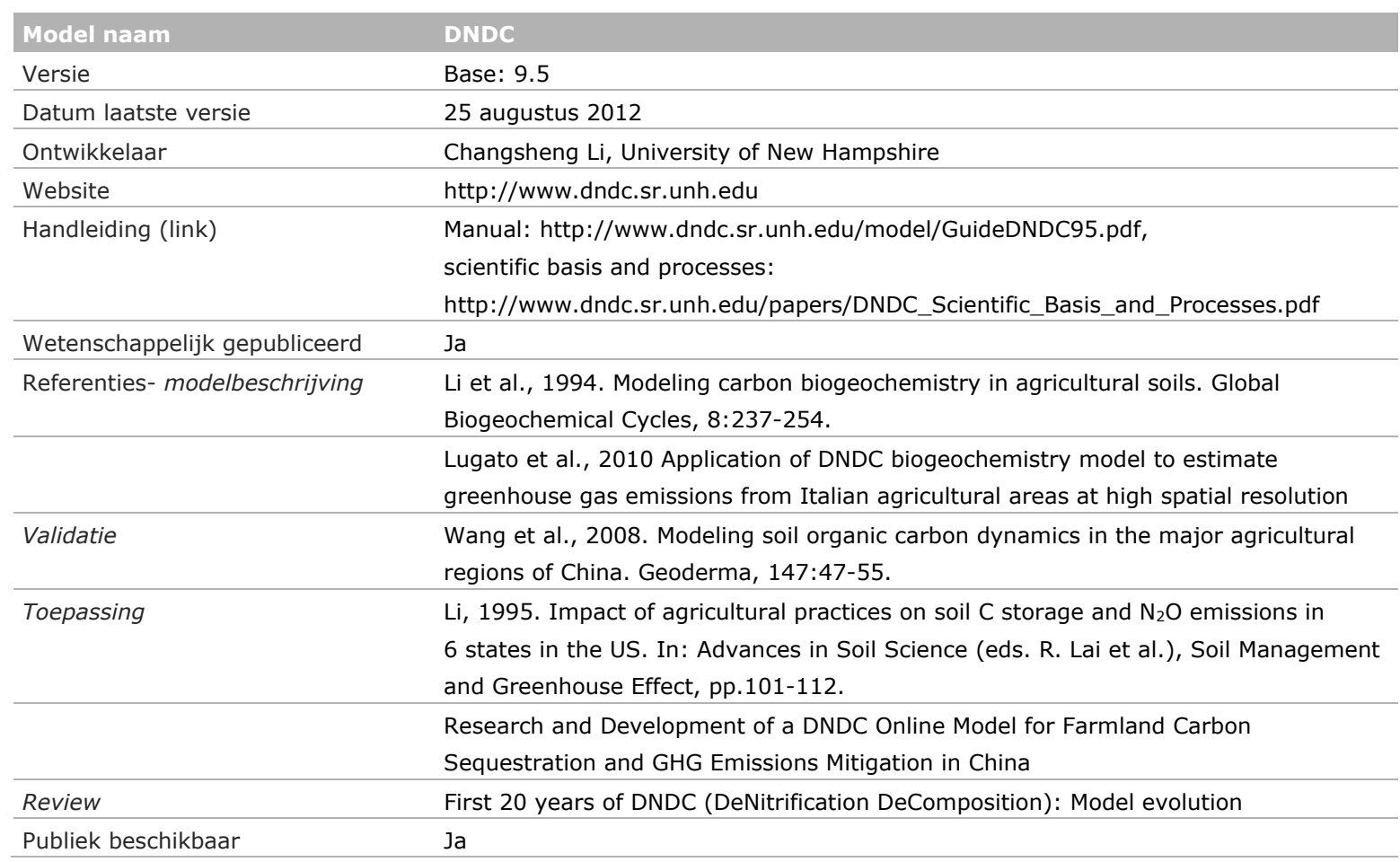




\begin{tabular}{|c|c|}
\hline Model naam & DNDC \\
\hline Licentie voor commercieel gebruik & Onbekend \\
\hline Code/rekenregels openbaar? & $\begin{array}{l}\text { CODE DNDC EUROPE: http://afoludata.jrc.ec.europa.eu/dataset/denitrification- } \\
\text { decomposition-model-dndc-adapted-application-europe-wide-scale/resource }\end{array}$ \\
\hline Temporele resolutie (reken tijdstap) & Dag \\
\hline Ruimtelijke resolutie & Plot tot nationaal \\
\hline \multicolumn{2}{|l|}{ Bodemdiepte/ bodemlagen } \\
\hline $\begin{array}{l}\text { Toepassingsgebied (qua klimaat, } \\
\text { bodems, landgebruik) }\end{array}$ & Natuurlijke en landbouwbodems, nat en droog, in gematigde gebieden \\
\hline Relatie met waterbalans? & Eigen waterbalans \\
\hline $\begin{array}{l}\text { Welke processen worden er } \\
\text { gemodelleerd? }\end{array}$ & Stikstofbalans, Koolstofbalans, Waterbalans, Plantengroei (optioneel) \\
\hline $\begin{array}{l}\text { Welke maatregelen kunnen } \\
\text { doorgerekend worden? }\end{array}$ & Grondbewerking, bouwplan \\
\hline \multicolumn{2}{|l|}{ Benodigde inputparameters } \\
\hline Outputparameters & $\begin{array}{l}\text { Opbrengst, microbiële activiteit, } \mathrm{C} \text { opslag, nitraatuitspoeling, } \mathrm{N}_{2} \mathrm{O}, \mathrm{NO}, \mathrm{NH}_{3}, \mathrm{CH}_{4} \text { en } \\
\mathrm{CO}_{2} \text {-emissies }\end{array}$ \\
\hline Type interface & $\begin{array}{l}\text { Locale GUI, online versie in ontwikkeling voor berekening C dynamiek in Chinese } \\
\text { landbouw. }\end{array}$ \\
\hline OS & Windows \\
\hline API beschikbaar of te maken? & Geen bestaande API, maar Sourcecode is in $\mathrm{C}++$ beschikbaar \\
\hline Gevalideerd? Waarvoor? & Ja, in Italië en China \\
\hline Bestaande (praktijk)toepassingen & Ja, in China, Europa en de VS zijn landbouwmaatregelen doorgerekend \\
\hline \multicolumn{2}{|l|}{ Bestaande implementaties (link) } \\
\hline Zwakke punten & $\begin{array}{l}\text { Lastig te initialiseren, hoge databehoefte, minder actieve ontwikkeling, } \\
\text { gefragmenteerd }\end{array}$ \\
\hline Sterke punten & Mechanistisch; Integratie $\mathrm{C} / \mathrm{N}$-model \\
\hline Overige opmerkingen & \\
\hline
\end{tabular}

\begin{tabular}{ll} 
Model naam & EPIC \\
Versie & v8.10 \\
\hline Datum laatste versie & 2004 \\
\hline Ontwikkelaar & Opdrachtgever: United States Department of Agriculture \\
& Maker: Blackland Research and Extension Center \\
\hline Website & https://epicapex.tamu.edu/model-executables/ \\
\hline Handleiding (link) & https://agrilifecdn.tamu.edu/epicapex/files/2015/10/EPIC.0810-User-Manual-Sept- \\
\hline Wetenschappelijk gepubliceerd & Ja.pdf \\
\hline Referenties - modelbeschrijving & Sharpley, A.N., and J.R. Williams, eds. 1990. EPIC - Erosion/Productivity Impact \\
& Calculator: 1. Model Documentation. Washington, DC: USDA Technical Bulletin \\
& No. 1768. \\
\hline Validatie & Is uitgebreid gevalideerd op het gebied van water, irrigeren, en bodemstikstof. \\
& Resultaten van validatie voor berekeningen van bodemkoolstof zijn niet gevonden. \\
\hline Toepassing & Putnam, J., J. Williams, and D. Sawyer. 1988. "Using the Erosion-Productivity \\
Impact Calculator (EPIC) to Estimate the Impact of Soil Erosion for the 1985 RCA \\
Appraisal." J. Soil Water Cons. 43(4): 321-26.
\end{tabular}




\begin{tabular}{|c|c|}
\hline Model naam & EPIC \\
\hline Review & https://www.card.iastate.edu/products/publications/pdf/05wp397.pdf \\
\hline Publiek beschikbaar & $\mathrm{Ja}$ \\
\hline Licentie voor commercieel gebruik & GNU General Public License $\odot$ agreement \\
\hline Code/rekenregels openbaar? & $\mathrm{Ja}$ \\
\hline Temporele resolutie (reken tijdstap) & Dag \\
\hline $\begin{array}{l}\text { Temporele extent (duur van } \\
\text { simulatie) }\end{array}$ & Honderden tot duizenden jaren \\
\hline Ruimtelijke resolutie & Perceelniveau tot ongeveer 1 ha \\
\hline Bodemdiepte/bodemlagen & 10 bodemlagen \\
\hline $\begin{array}{l}\text { Toepassingsgebied (qua klimaat, } \\
\text { bodems, landgebruik) }\end{array}$ & $\begin{array}{l}\text { Het model is ontwikkeld voor Texas en VS, maar ook aangepast en gevalideerd voor } \\
\text { o.a. gewassen in zuid Frankrijk. }\end{array}$ \\
\hline $\begin{array}{l}\text { Stikstofinteracties? (incl. } \mathrm{N}_{2} \mathrm{O}- \\
\text { emissies) }\end{array}$ & Ja, maar vooral $\mathrm{N}$-uitspoeling, $\mathrm{N}$-afspoeling, $\mathrm{P}$-afspoeling en $\mathrm{N}$-effecten op productie. \\
\hline Relatie met waterbalans? & $\mathrm{Ja}$ \\
\hline $\begin{array}{l}\text { Welke processen worden er } \\
\text { gemodelleerd? }\end{array}$ & - \\
\hline $\begin{array}{l}\text { Welke maatregelen kunnen } \\
\text { doorgerekend worden? }\end{array}$ & $\begin{array}{l}\text { Bodembewerking, irrigatie, rotaties, pesticiden en verliezen hiervan, en minerale } \\
\text { meststof input. Maar het model is voornamelijk bedoeld voor het doorrekenen van } \\
\text { effecten op erosie. }\end{array}$ \\
\hline Benodigde inputparameters & $\begin{array}{l}\text { Locatie, bodemgegevens, klimaatgegevens, gewasdata, grondbewerking, bemesting, } \\
\text { en toediening van bestrijdingsmiddelen. }\end{array}$ \\
\hline Outputparameters & Dit model genereert veel outputparameters, o.a. opbrengst en bodemkoolstof. \\
\hline Export format & .out files (Deze kunnen geopend worden met Excel). \\
\hline Beschrijving OS-/C-pools & $\begin{array}{l}\text { Dit model heet drie OS-/C-pools: snel (microbieel, dagen of weken), langzaam en } \\
\text { passief, gebaseerd op Century. Bij deze pools zit erosie er heel expliciet in. }\end{array}$ \\
\hline SOM-dynamiek & De drie pools hebben elk hun eigen afbraaksnelheden. \\
\hline $\begin{array}{l}\text { OS-/C-pools meetbaar of } \\
\text { conceptueel }\end{array}$ & Beide \\
\hline Type interface & $\begin{array}{l}\text { versie is te downloaden en draait op computer, er zijn grafische interfaces (winaEPIC } \\
\text { en iEPIC) om in beeld te brengen wat er uit komt }\end{array}$ \\
\hline OS & Allerhande, Windows is prima \\
\hline API beschikbaar of te maken? & Ja, programmeertaal is fortran \\
\hline Gevalideerd? Waarvoor? & $\begin{array}{l}\text { Vooral voor productie, ook wel voor N-niveaus in bodem, beperkt voor OS- } \\
\text { hoeveelheid. Niet gevalideerd voor Nederlandse omstandigheden. }\end{array}$ \\
\hline Bestaande (praktijk)toepassingen & Het model is in diverse andere wetenschappelijke modellen geïntegreerd. \\
\hline \multicolumn{2}{|l|}{ Bestaande implementaties (link) } \\
\hline Zwakke punten & $\begin{array}{l}\text { Het model is ontwikkeld om de interacties tussen erosie, klimaatsverandering en } \\
\text { gewasproductie te simuleren. Bodemkoolstof- veranderingen staan niet centraal in } \\
\text { dit model. }\end{array}$ \\
\hline Sterke punten & $\begin{array}{l}\text { Met dit model kunnen ook maatregelen als grondbewerking doorgerekend worden. } \\
\text { Het is alleen niet bekend of dit slechts effect heeft op het afstromen van bodem door } \\
\text { water of ook op effecten op OS in de grond. }\end{array}$ \\
\hline
\end{tabular}

Overige opmerkingen

\begin{tabular}{ll} 
Model naam & NDICEA \\
Versie & 6.2 \\
\hline Datum laatste versie & 2014 \\
\hline Ontwikkelaar & Louis Bolk Instituut, in eerste instantie i.s.m. Wageningen Universiteit \\
\hline Website & http://www.ndicea.nl/indexnl.php?i=nlnieuw \\
\hline Handleiding (link) & http://www.ndicea.nl/docs/Handleiding_NL_NDICEA_6_2.pdf \\
\hline Wetenschappelijk gepubliceerd & Ja \\
\hline Referenties - modelbeschrijving & Van der Burgt GFHM, Oomen GJM, Hobets ASJ, Rossing WAH (2006) The NDICEA \\
& model, a tool to improve nitrogen use efficiency in cropping systems. Nutr Cycl \\
& Agroecosyst 74, pp. 275-294 \\
\hline Validatie & https://www.researchgate.net/publication/240498603_Nitrogen_mineralisation_in_o \\
& rganic_farming_systems_A_test_of_the_NDICEA_model
\end{tabular}




\begin{tabular}{|c|c|}
\hline Model naam & NDICEA \\
\hline Toepassing & $\begin{array}{l}\text { Als learning tool (http://orgprints.org/7210/); als management tool } \\
\text { (http://orgprints.org/15860/) }\end{array}$ \\
\hline Licentie voor commercieel gebruik & $\mathrm{Ja}$ \\
\hline Code/rekenregels openbaar? & $\mathrm{Ja}$ \\
\hline Temporele resolutie (reken tijdstap) & Dag \\
\hline $\begin{array}{l}\text { Temporele extent (duur van } \\
\text { simulatie) }\end{array}$ & 1 tot 12 jaar \\
\hline Ruimtelijke resolutie & Punt of perceelniveau \\
\hline $\begin{array}{l}\text { Stikstofinteracties? (incl. } \mathrm{N}_{2} \mathrm{O}- \\
\text { emissies) }\end{array}$ & $\mathrm{Ja}$ \\
\hline Relatie met waterbalans? & $\mathrm{Ja}$ \\
\hline $\begin{array}{l}\text { Welke processen worden er } \\
\text { gemodelleerd? }\end{array}$ & $\begin{array}{l}\text { Afbraak van organische stof, waarbij C en } \mathrm{N} \text { vrijkomen in diverse vormen. Gericht op } \\
\text { akkerbouw /grasland en in rotatie (landbouwmanagement). Veel verschillende typen } \\
\text { bemesting en gewassen en groenbemesters zitten erin. }\end{array}$ \\
\hline $\begin{array}{l}\text { Welke maatregelen kunnen } \\
\text { doorgerekend worden? }\end{array}$ & $\begin{array}{l}\text { Rotatie en wisselingen hierin, grondbewerking ruw (intensief tot extensief), hogere } \\
\text { of lagere input organische stof, andere soort organische stof etc. }\end{array}$ \\
\hline Beschrijving OS-/C-pools & $\begin{array}{l}\text { Continu - van elke input van organisch materiaal wordt separaat de afbraak } \\
\text { berekend, dus zeer veel kleine pools die verschillen in afbraaksnelheid. }\end{array}$ \\
\hline SOM-dynamiek & $\begin{array}{l}\text { Afbraakcurve zoals gepubliceerd door Jansen in } 1984 \text { en 1996, } 2 \text { parameters } \\
\text { (apparent initial age and humificationcoefficient), beïnvloed door C: N, lignine en } \\
\text { polyfenolen }\end{array}$ \\
\hline $\begin{array}{l}\text { OS-/C-pools meetbaar of } \\
\text { conceptueel }\end{array}$ & Totale pool meetbaar, subverdeling niet \\
\hline Type interface & Stand-alone op computer, EXE-file \\
\hline OS & Windows \\
\hline API beschikbaar of te maken? & Niet beschikbaar, wel te maken \\
\hline Gevalideerd? Waarvoor? & $\begin{array}{l}\text { Met name voor stikstofdynamiek in percelen. Langetermijnproeven geven } \\
\text { mogelijkheid op validatie met OS in bodem. }\end{array}$ \\
\hline Bestaande (praktijk)toepassingen & Door bedrijven met planning, door adviseurs \\
\hline Bestaande implementaties (link) & Niet bekend \\
\hline Zwakke punten & $\begin{array}{l}\text { Programmataal is verouderd, niet gemakkelijk toegankelijk en voor automatisch } \\
\text { invullen net te detaillistisch om goed te kunnen rekenen door specifieke info over } \\
\text { gewassen en timing van gewassen. }\end{array}$ \\
\hline
\end{tabular}

Overige opmerkingen

\begin{tabular}{ll} 
Model naam & ORCHIDEE \\
Versie & 2.0 \\
\hline Datum laatste versie & 2018 \\
\hline Ontwikkelaar & Team van ontwikkelaars (en open source): o.a. diverse labs van het Franse National \\
& Center for Scientific Research (CNRS) en de Vrije Universiteit van Amsterdam (groep \\
& Systems Ecology). \\
\hline Website & https://orchidee.ipsl.fr/you-orchidee/; https://forge.ipsl.jussieu.fr/orchidee/browser \\
\hline Handleiding (link) & https://forge.ipsl.jussieu.fr/orchidee/wiki/Documentation/UserGuide\#Howtosection \\
\hline Wetenschappelijk gepubliceerd & \\
\hline
\end{tabular}


Model naam

Referenties- modelbeschrijving
ORCHTDEF

Krinner, G.; Viovy, N.; de Noblet-Ducoudré, N.; Ogée, J.; Polcher, J.;

Friedlingstein, P.; Ciais, P.; Sitch, S.; Prentice, I. C. A dynamic global vegetation model for studies of the coupled atmosphere-biosphere system. Glob. Biogeochem. Cycles, 2005, 19 (1).

Wu, X.; Vuichard, N.; Ciais, P.; Viovy, N.; de Noblet-Ducoudré, N.; Wang, X.; Magliulo, V.; Wattenbach, M.; Vitale, L.; Tommasi, P. D.; Moors, E. J.; Jans, W.; Elbers, J.; Ceschia, E.; Tallec, T.; Bernhofer, C.; Grünwald, T.; Moureaux, C.; Manise, T.; Ligne, A.; Cellier, P.; Loubet, B.; Larmanou, E. \& Ripoche, D. ORCHIDEECROP ( $v 0)$, a new process based Agro-Land Surface Model: model description and evaluation over Europe Geosci. Model Dev., 2016, 9, 857-873

\begin{tabular}{l} 
Validatie \\
\hline Toepassing \\
\hline Review \\
\hline Publiek beschikbaar \\
\hline Licentie voor commercieel gebruik \\
Code/rekenregels openbaar?
\end{tabular}

Temporele resolutie (reken Verschillende

tijdstap)

Temporele extent (duur van Van 15 minuten tot meerdere jaren

simulatie)

Ruimtelijke resolutie van 1 gridpunt op kaart tot globaal

Bodemdiepte/ bodemlagen 0-2 meter diepte, verschillend voor energie (warmte) en voor waterflux Toepassingsgebied (qua klimaat, bodems, landgebruik)

idem

idem

Fair Use Policy for ORCHIDEE: https://orchidee.ipsl.fr/you-orchidee/

Het model is wereldwijd toepasbaar, maar lijkt meer geschikt voor wilde natuur en vegetaties en bossen dan voor nuanceverschillen in gewassen. $\mathrm{Er}$ is echter een evolution, de ORCHIDEE-STICS koppeling, die het misschien beter mogelijk maakt, maar dan wordt het wel complexer.

\section{Stikstofinteracties? (incl. $\mathrm{N}_{2} \mathrm{O}-\quad$ Niet in bodem}

emissies)

\begin{tabular}{|c|c|}
\hline Relatie met waterbalans? & Wel uitspoeling en verlies van dissolved organic matter (DOC) \\
\hline $\begin{array}{l}\text { Welke processen worden er } \\
\text { gemodelleerd? }\end{array}$ & Veel verschillende processen \\
\hline $\begin{array}{l}\text { Welke maatregelen kunnen } \\
\text { doorgerekend worden? }\end{array}$ & Verandering in landgebruik, van bijv. bos naar grasland of naar akkerland \\
\hline Benodigde inputparameters & $\begin{array}{l}\text { Ongeveer } 400 \text { parameters. } \\
\text { https://forge.ipsl.jussieu.fr/orchidee/wiki/Documentation/OrchideeParameters }\end{array}$ \\
\hline Outputparameters & Veel outputparameters waaronder, biomassa, fotosynthese, bodem organische stof. \\
\hline Export format & .nc files (numerical control) \\
\hline Beschrijving OS-/C- pools & $\begin{array}{l}\text { DOC (dissolved organic matter) en drie pools, 'active', 'slow' en 'passive', } \\
\text { vergelijkbaar met Century. Afbraak snelheden hangen af van vochtgehalte en van } \\
\text { temperatuur. }\end{array}$ \\
\hline SOM-dynamiek & In uitwisseling met vegetatie, atmosfeer en waterstromen. \\
\hline $\begin{array}{l}\text { OS-/C-pools meetbaar of } \\
\text { conceptueel }\end{array}$ & Totale SOC en DOC zijn meetbaar, onderverdeling is conceptueel. \\
\hline Type interface & Onbekend \\
\hline OS & Werkt op meerdere \\
\hline API beschikbaar of te maken? & Nee, maar wel hulp hoe het te doen online \\
\hline Gevalideerd? Waarvoor? & $\begin{array}{l}\text { Voor vele modules en situaties, maar nog niet voor SOC in bodems op diepte in } \\
\text { Europa, daarvoor zijn ze net in aanpassing, zie: } \\
\text { https://ddd.uab.cat/pub/artpub/2018/189291/Camino_et_al_GeosciModDev_2018.pdf }\end{array}$ \\
\hline Bestaande (praktijk)toepassingen & Veel gebruikt in publicaties in het kader van klimaatsverandering \\
\hline Bestaande implementaties (link) & Onbekend \\
\hline Zwakke punten & $\begin{array}{l}\text { Grof en eigenlijk niet voor landbouw gemaakt. Als dit model toegepast wordt, wordt } \\
\text { het model complexer en omvangrijker. }\end{array}$ \\
\hline Sterke punten & $\begin{array}{l}\text { Koppelingen mogelijk, zowel met datasets ter opschaling, als met agronomische } \\
\text { submodellen, bijv. ORCHIDEE-STICS. }\end{array}$ \\
\hline
\end{tabular}

Overige opmerkingen 


\begin{tabular}{|c|c|}
\hline Model naam & OS balans NMI \\
\hline Versie & 1.2 .0 \\
\hline Datum laatste versie & Onbekend \\
\hline Website & https://os-balans.nl \\
\hline Handleiding (link) & $\begin{array}{l}\text { https://www.milieukeur.nl/Public/Milieukeur_Agro_Food_Plantaardig_open_teelt_Sche } \\
\text { ma/HANDLEIDINGOS-tool.pdf }\end{array}$ \\
\hline Wetenschappelijk gepubliceerd & Nee \\
\hline \multicolumn{2}{|l|}{ Referenties } \\
\hline Publiek beschikbaar & $\mathrm{Ja}$ \\
\hline Licentie voor commercieel gebruik & Onbekend \\
\hline $\begin{array}{l}\text { Temporele extent (duur van } \\
\text { simulatie) }\end{array}$ & 3 jaar \\
\hline Ruimtelijke resolutie & Perceelniveau \\
\hline Bodemdiepte/bodemlagen & Onbekend \\
\hline $\begin{array}{l}\text { Toepassingsgebied (qua klimaat, } \\
\text { bodems, landgebruik) }\end{array}$ & Akkerbouw, vollegrondsgroenteteelt en de boomkwekerij in Nederland \\
\hline $\begin{array}{l}\text { Stikstofinteracties? (incl. } \mathrm{N}_{2} \mathrm{O}- \\
\text { emissies) }\end{array}$ & Geen \\
\hline Benodigde inputparameters & Bouwplan, bodem-organischestofgehalte, kleigehalte, aan- en afvoer gewasresten \\
\hline Outputparameters & Organisch stof aanvoer en afvoer \\
\hline Export format & GUI \\
\hline Beschrijving OS-/C-pools & Onbekend \\
\hline SOM-dynamiek & Onbekend \\
\hline \multicolumn{2}{|l|}{$\begin{array}{l}\text { OS-/C-pools meetbaar of } \\
\text { conceptueel }\end{array}$} \\
\hline Type interface & Web, local GUI \\
\hline OS & Windows \\
\hline API beschikbaar of te maken? & Nee \\
\hline Gevalideerd? Waarvoor? & Onbekend \\
\hline Bestaande (praktijk)toepassingen & Milieukeur \\
\hline Bestaande implementaties (link) & https://os-balans.nl/bedrijf.html \\
\hline Zwakke punten & $\begin{array}{l}\text { Lijkt slechts met forfaitaire getallen te werken voor decompositie. Werkt niet voor } \\
\text { grasland }\end{array}$ \\
\hline Sterke punten & Gebruikersvriendelijk voor een agrariër \\
\hline Overige opmerkingen & \\
\hline
\end{tabular}

\begin{tabular}{ll} 
Model naam & RothC \\
Versie & RothC-26.3, version 2.1 \\
\hline Datum laatste versie & 7.04 .2009 \\
\hline Ontwikkelaar & Rothamsted Research UK \\
\hline Website & https://www.rothamsted.ac.uk/rothamsted-carbon-model-rothc \\
\hline Handleiding (link) & https://www.rothamsted.ac.uk/sites/default/files/RothC_guide_WIN.pdf \\
\hline Wetenschappelijk gepubliceerd & Ja \\
\hline Referenties - modelbeschrijving & Coleman, K., Jenkinson, D.S., 1996. RothC-26.3 - A model for the turnover of carbon \\
& in soil. In: Powlson, D.S., Smith, P., Smith, J.U. (Eds.), Evaluation of Soil Organic \\
& Matter Models Using Existing Long-Term Datasets. Springer-Verlag, Heidelberg, \\
& pp. 237-246.
\end{tabular}


Model naam

Validatie

Coleman, K., Jenkinson, D.S., Crocker, G.J., Grace, P.R., Klir, J., Korschens, M., Poulton, P.R., Richter, D.D., 1997. Simulating trends in soil organic carbon in longterm experiments using RothC-26.3. Geoderma 81, 29-44.

Toepassing

Cerri, C.E.P., Easter, M., Paustian, K., Killian, K., Coleman, K., Bernoux, M.,

Falloon, P., Powlson, D.S., Batjes, N.H., Milne, E., Cerri, C.C., 2007. Predicted soil organic carbon stocks and changes in the Brazilian Amazon between 2000 and 2030.

Agric., Ecosyst. Environ. 122, 58-72.

Mondini, C., Coleman, K., Whitmore, A.P., 2012. Spatially explicit modelling of changes in soil organic $C$ in agricultural soils in Italy, 2001-2100: Potential for compost amendment. Agric., Ecosyst. Environ. 153, 24-32.

Review Smith, P., Smith, J.U., Powlson, D.S., McGill, W.B., Arah, J.R.M., Chertov, O.G., Coleman, K., Franko, U. et al. (1997): A comparison of the performance of nine soil organic matter models using datasets from seven long-term experiments. Geoderma, 81 , S. $153-225$

Byrne, Kenneth \& Kiely, Ger. (2009). Evaluation of Models (PaSim, RothC, CENTURY and DNDC) for Simulation of Grassland Carbon Cycling at Plot, Field and Regional Scale.

Publiek beschikbaar Ja

Licentie voor commercieel gebruik Op aanvraag bij copyright houder (Rothamsted Research)

Code/rekenregels openbaar? Beschikbaar op aanvraag, WUR beschikt over de code

Temporele resolutie (reken Maand

tijdstap)

Temporele extent (duur van Jaren tot eeuwen

simulatie)

Ruimtelijke resolutie Plot, perceel, regionaal en wereldwijd

Bodemdiepte/bodemlagen $\quad$ RothC is ontwikkeld voor topsoils tot $25 \mathrm{~cm}$ en bevat 1 bodemlaag.

Toepassingsgebied (qua klimaat, Akkerbouw, grasland en bosgebieden op minerale gronden.

bodems, landgebruik) De nieuwe RothPC is voor vulkanische en droge bodems.

Verschillende klimaatzones.

Stikstofinteracties? (incl. $\mathrm{N}_{2} \mathrm{O}-\quad$ Wel in Roth-CNP

emissies)

(K. Coleman, S.E. Muhammed, A.E. Milne, L.C. Todman, A.G. Dailey, M.J. Glendining, et al.

The landscape model: a model for exploring trade-offs between agricultural production and the environment Sci. Total Environ., 609 (2017), pp. 1483-149)

Relatie met waterbalans? Op basis van maandelijkse neerslag en verdamping wordt overschot/tekort berekent, wat invloed heeft op de afbraakfactoren.

Welke processen worden er Koolstofbalans

gemodelleerd?

Welke maatregelen kunnen Bouwplan, organische stof input

doorgerekend worden?

Benodigde inputparameters

Kleigehalte, maandelijkse temperatuur, neerslag en evapotranspiratie, gewasdekking, aanvoer gewasresten en mest, schatting van de afbreekbaarheid van het aangevoerde plantmateriaal (DPM/RPM-ratio), diepte van de bemonsterde bodemlaag Optioneel: ${ }^{14} \mathrm{C}$ van OS

Outputparameters Totale bodemkoolstofvoorraad op maandelijkse of jaarlijkse intervallen en de verdeling over de verschillende pools. Daarnaast geeft het ook een ${ }^{14} \mathrm{C}$ - waarde voor elke tijdstap en een schattig van $\mathrm{CO}_{2}$-verlies door afbraak van organisch materiaal.

Export format ASCII output files

Beschrijving OS-/C-pools Vijf OS-/C-pools in totaal. Vier actieve pools: Decomposable Plant Material (DPM), Resistant Plant Material (RPM), Microbial Biomass (BIO) en Humified Organic Matter (HUM). En één inactieve pool: Inert Organic Matter (IOM).

SOM-dynamiek Elke pool heeft een vaste afbraaksnelheid. De afbraaksnelheden worden beïnvloed door temperatuur, vochtgehalte en aanwezigheid van vegetatie.

OS-/C-pools meetbaar of Conceptueel

conceptueel

Type interface Local GUI 
API beschikbaar of te maken?

Nee, wel te maken, in project met FrieslandCampina wordt gewerkt aan koppeling met Kringloopwijzer database

Gevalideerd? Waarvoor? Ja, meerdere studies.

Bestaande (praktijk)toepassingen Miterra-NL (WEnR) gebruikt in beleidsverkenningen, Roth-C is de basis voor de $C$ module in de Klimaatlat van CLM. Roth-C is ingebouwd in de soil fertility toolkit en BioEsoil tool (WEnR), Roth-C is de basis van het Belgische bodem C model C-slim.

Bestaande implementaties (link) Klimaatlat (www.klimaatlat.nl) CSLIM (http://bdbnet.bdb.be/pls/apex/f?p=131:48:234561551889823::NO) BioESoil (www.bioesoil.org),

Zwakke punten Grondbewerking kan nog niet doorgerekend worden en model kan niet gebruikt worden voor bodems met een hoog OS-gehalte. Aanvoer $\mathrm{C}$ uit gewasresten grasland nog grote onzekerheid (maar geldt voor alle modellen).

Sterke punten Relatief lage databehoefte, al veel toegepast en beschreven in de literatuur.

Overige opmerkingen Contact: Kevin Coleman kevin.coleman@rothamsted.ac.uk 
Wageningen Environmental Research Postbus 47

6700 AA Wageningen

T 0317480700

www.wur.nl/environmental-research

Wageningen Environmental Research Rapport 2990

ISSN 1566-7197
De missie van Wageningen University \& Research is 'To explore the potential of nature to improve the quality of life'. Binnen Wageningen University \& Research bundelen Wageningen University en gespecialiseerde onderzoeksinstituten van Stichting Wageningen Research hun krachten om bij te dragen aan de oplossing van belangrijke vragen in het domein van gezonde voeding en leefomgeving. Met ongeveer 30 vestigingen, 5.000 medewerkers en 12.000 studenten behoort Wageningen University \& Research wereldwijd tot de aansprekende kennisinstellingen binnen haar domein. De integrale benadering van de vraagstukken en de samenwerking tussen verschillende disciplines vormen het hart van de unieke Wageningen aanpak. 



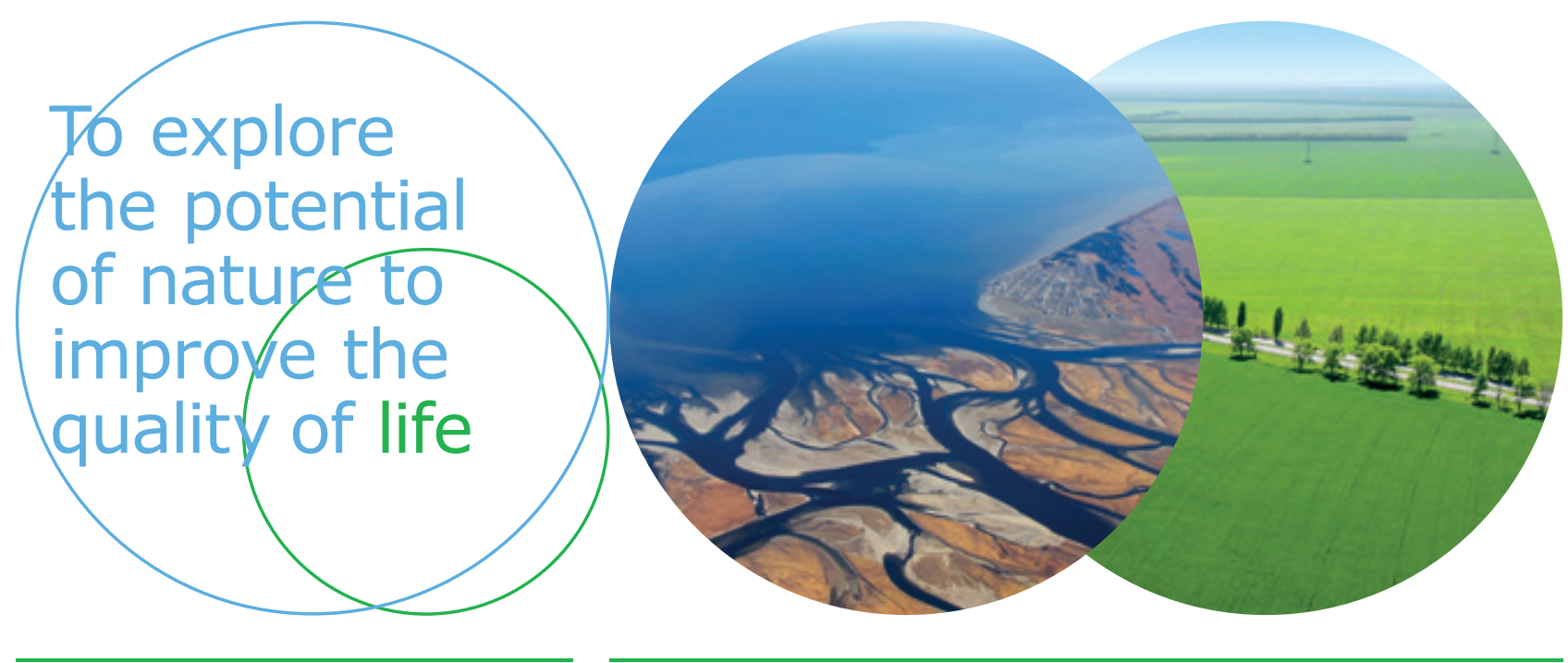

Wageningen Environmental Research Postbus 47

$6700 \mathrm{AB}$ Wageningen

T 317480700

www.wur.nl/environmental-research

Rapport 2990

ISSN 1566-7197
De missie van Wageningen University \& Research is 'To explore the potential of nature to improve the quality of life'. Binnen Wageningen University \& Research bundelen Wageningen University en gespecialiseerde onderzoeksinstituten van Stichting Wageningen Research hun krachten om bij te dragen aan de oplossing van belangrijke vragen in het domein van gezonde voeding en leefomgeving. Met ongeveer 30 vestigingen, 5.000 medewerkers en 12.000 studenten behoort Wageningen University \& Research wereldwijd tot de aansprekende kennisinstellingen binnen haar domein. De integrale benadering van de vraagstukken en de samenwerking tussen verschillende disciplines vormen het hart van de unieke Wageningen aanpak. 